\title{
The Itajaí foreland basin: a tectono-sedimentary record of the Ediacaran period, Southern Brazil
}

\author{
M. A. S. Basei - C. O. Drukas • A. P. Nutman $\cdot$ K. Wemmer $\cdot$ L. Dunyi $\cdot$ \\ P. R. Santos - C. R. Passarelli - M. C. Campos Neto • O. Siga Jr • \\ L. Osako
}

Received: 8 April 2010/Accepted: 5 September 2010/Published online: 21 October 2010

(C) Springer-Verlag 2010

\begin{abstract}
The Itajaí Basin located in the southern border of the Luís Alves Microplate is considered as a peripheral foreland basin related to the Dom Feliciano Belt. It presents an excellent record of the Ediacaran period, and its upper parts display the best Brazilian example of Precambrian turbiditic deposits. The basal succession of Itajaí Group is represented by sandstones and conglomerates (Baú Formation) deposited in alluvial and deltaic-fan systems. The marine upper sequences correspond to the Ribeirão Carvalho (channelized and non-channelized proximal silty-argillaceous rhythmic turbidites), Ribeirão Neisse (arkosic sandstones and siltites), and Ribeirão do Bode (distal silty turbidites) formations. The Apiúna Formation felsic volcanic rocks crosscut the sedimentary succession. The Cambrian Subida leucosyenogranite represents the last felsic magmatic activity to affect the Itajaí
\end{abstract}

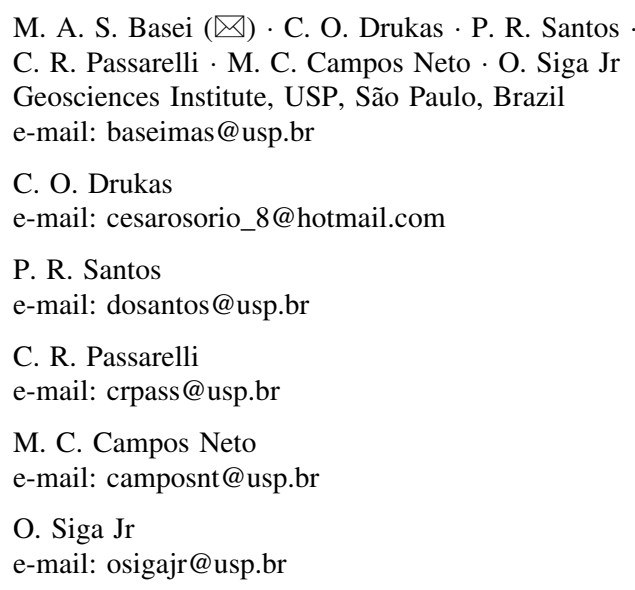

Basin. The Brusque Group and the Florianópolis Batholith are proposed as source areas for the sediments of the upper sequence. For the lower continental units the source areas are the Santa Catarina, São Miguel and Camboriú complexes. The lack of any oceanic crust in the Itajaí Basin suggests that the marine units were deposited in a restricted, internal sea. The sedimentation started around $600 \mathrm{Ma}$ and ended before $560 \mathrm{Ma}$ as indicated by the emplacement of rhyolitic domes. The Itajaí Basin is temporally and tectonically correlated with the Camaquã Basin in Rio Grande do Sul and the Arroyo del Soldado/Piriápolis Basin in Uruguay. It also has several tectono-sedimentary characteristics in common with the African-equivalent Nama Basin.

Keywords Dom Feliciano Belt - Ediacaran - Foreland basin - U-Pb SHRIMP ages · Provenance

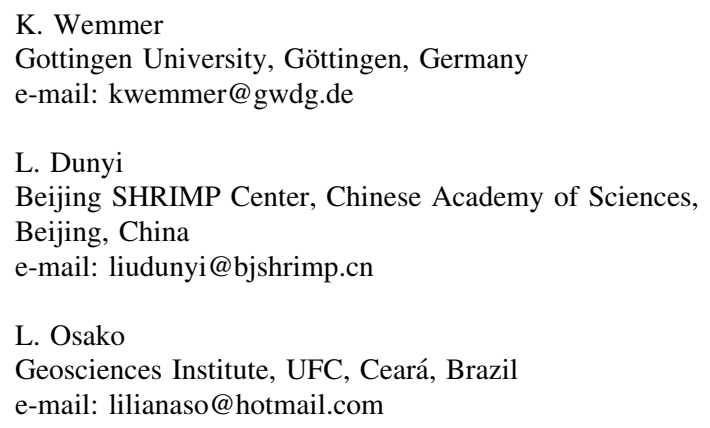




\section{Introduction}

The best record of the transition between the collisional events that culminated with the constitution of the western Gondwana (end of the Ediacaran) and the stable conditions that enabled the installation of the Paraná Basin (Lower Paleozoic) is found in the northern portion of southern Brazil, in a series of sedimentary and volcano-sedimentary basins that do not show the deformation and metamorphism that characterize the units in the adjacent fold belts.

Among the existing Neoproterozoic basins (the Itajaí, Camarinha, Corupá, Campo Alegre, Guaratubinha, and Castro basins) can be divided into two major groups: foreland and extensional basins (continental rifts): The Camarinha and Itajaí basins, which are predominantly sedimentary and situated at the borders of the Ribeira and Dom Feliciano belts respectively, are interpreted as peripheral foreland basins. The Castro, Guaratubinha, Campo Alegre, and Corupá basins are extensional and were installed on an old gneissic substrate. They are predominantly filled with bimodal volcanic material, and are here classified as continental rifts.

Except for the Castro Basin, which is the youngest of all (ca. $550 \mathrm{Ma}$ ), the available radiometric information indicates that the main magmatic phase that affected the extensional basins ( $c a .600 \mathrm{Ma}$ ) preceded up to $40 \mathrm{Ma}$ that of the Itajaí foreland basin ( $c a$. $560 \mathrm{Ma}$ ), with both magmatic events taking place between the two main compressional periods of 610 and 535 Ma that can be observed in southern Brazil. Despite older, but due to their intraplate setting, the extensional basins are undeformed, whereas the Itajaí and Camarinha foreland basins clearly record deformation associated with the proximity of the adjacent belts.

\section{Geologic Context of Itajaí Basin}

The northeastern portion of southeastern Brazil encompasses five tectonic domains, juxtaposed around $600 \pm 10 \mathrm{Ma}$ as part of the western Gondwana assembly processes (Fig. 1). Two of the four major domains are constituted by the Paleoproterozoic gneissic-migmatitic rocks of the Curitiba and Luís Alves Microplates, which separate the Neoproterozoic Ribeira $(\mathrm{N})$ and Dom Feliciano (S) belts from one another. The fifth segment occurs in the coastal region, being represented by the Neoproterozoic Costeiro Granitic Belt, constituted by a variety of granitoids and supracrustal remnants (Basei et al. 1998b).

The Ribeira Belt is predominantly composed of Mesoproterozoic metasedimentary successions deposited in a passive margin setting on the eastern edge of the Paranapanema Craton. In the Neoproterozoic, this belt behaved as an active margin, and was intensely affected by calc- alkaline magmatism represented by large granitic batholiths that constitute the roots of the Neoproterozoic Três Córregos, Cunhaporanga, and Agudos Grandes magmatic arcs. The main metamorphism and deformation overprints also occurred at this time (Basei et al. 1992, Siga et al. 2009).

The granulite-migmatitic terrains that constitute the basement of the Curitiba Microplate were grouped into the Atuba Complex (Siga et al. 1995). These are constituted by banded biotite-amphibole gneisses, amphibolites, and a variety of granitoids, which underwent medium- to highgrade metamorphism. The history of these gneisses starts with magmatism in the Mesoarchean, around 3.0 Ga (Sato et al. 2003), with a first migmatization phase in the Orosirian $(\sim 2,100 \mathrm{Ma})$ and a second migmatization phase by the end of the Ediacaran ( $~ 600 \mathrm{Ma})$. The Atuba Complex has a metasedimentary cover (Capiru and Setuva Formations) probably of Neoproterozoic age and is crosscut by several Ediacaran anorogenic granitoids.

The Santa Catarina Granulitic Complex (Hartmann et al. 1979; Kaul 1980; Basei et al. 2009) is a crustal segment consisting of high-grade metamorphic rocks, predominantly charno-enderbites and migmatitic gneisses with occasional mafic-ultramafic bodies and paragneiss remnants. The Campo Alegre Basin ( 600 Ma) represents the main cover recognized in the Luis Alves Microplate central region. The north-northeast limit with the Curitiba Microplate is defined by the Piên Suture Zone (Basei et al. 1992; Machiavelli et al. 1993; Harara 2001, Harara et al. 2002).

The evolution of the Santa Catarina Granulitic Complex started with the emplacement of a 2,600 Ma TTG suite, which was later affected by regional, Siderian (2,350 Ma) granulite-facies metamorphism and by an Orosirian (2,000 Ma) granulite/amphibolite-facies metamorphic event (Basei et al. 2009). After $\sim 1,900 \mathrm{Ma}$, the region became tectonically stable and was the only block in the southeastern Brazil that remained cold $\left(<300^{\circ} \mathrm{C}\right)$ since the end of the Paleoproterozoic, showing no evidence of the Neoproterozoic tectono-thermal overprint that is characteristic of the other terranes in the region. Its southern border is covered with the Itajaí Basin sediments, which are in tectonic contact with the Dom Feliciano Belt supracrustal rocks, with inverse faulting responsible for tectonic imbrications related to low-angle thrusts. The domain situated farther south is represented by the Dom Feliciano Belt northern termination. As the other segments of this Belt, it is internally organized into three major compartments (Fig. 2): the Granitoid Belt (Florianópolis Batholith arc-related granitoids), the Schist Belt (Brusque Group sedimentary covers metamorphosed to the greenschist- to amphibolitefacies), and the Foreland Belt (Itajaí Basin supracrustal rocks). 
Fig. 1 Tectonic domains resulting from the amalgamation of Western Gondwana. 1 Tertiary and quaternary covers; 2 Paraná Basin; 3 Serra do Mar Suite Granites; 4 Campo Alegre Basin, 5 Ribeira Belt Southern Portion; 6 Capiru and Setuba Metasedimentary sequences; 7 Atuba Complex; 8 Rio Piên Batholith; 9 Costeiro Granitic Belt (Paranaguá and Mongaguá Batholiths); 10 Santa Catarina Granulitic Complex; 11 Itajaí Foreland Basin; 12 Brusque Group; 13 Camboriu Complex; 14 Granitoid Belt (Florianópolis Batholith); 15 thrusting; 16 inferred contact; 17 tectonic transport (Simplified after Basei et al. 2009)

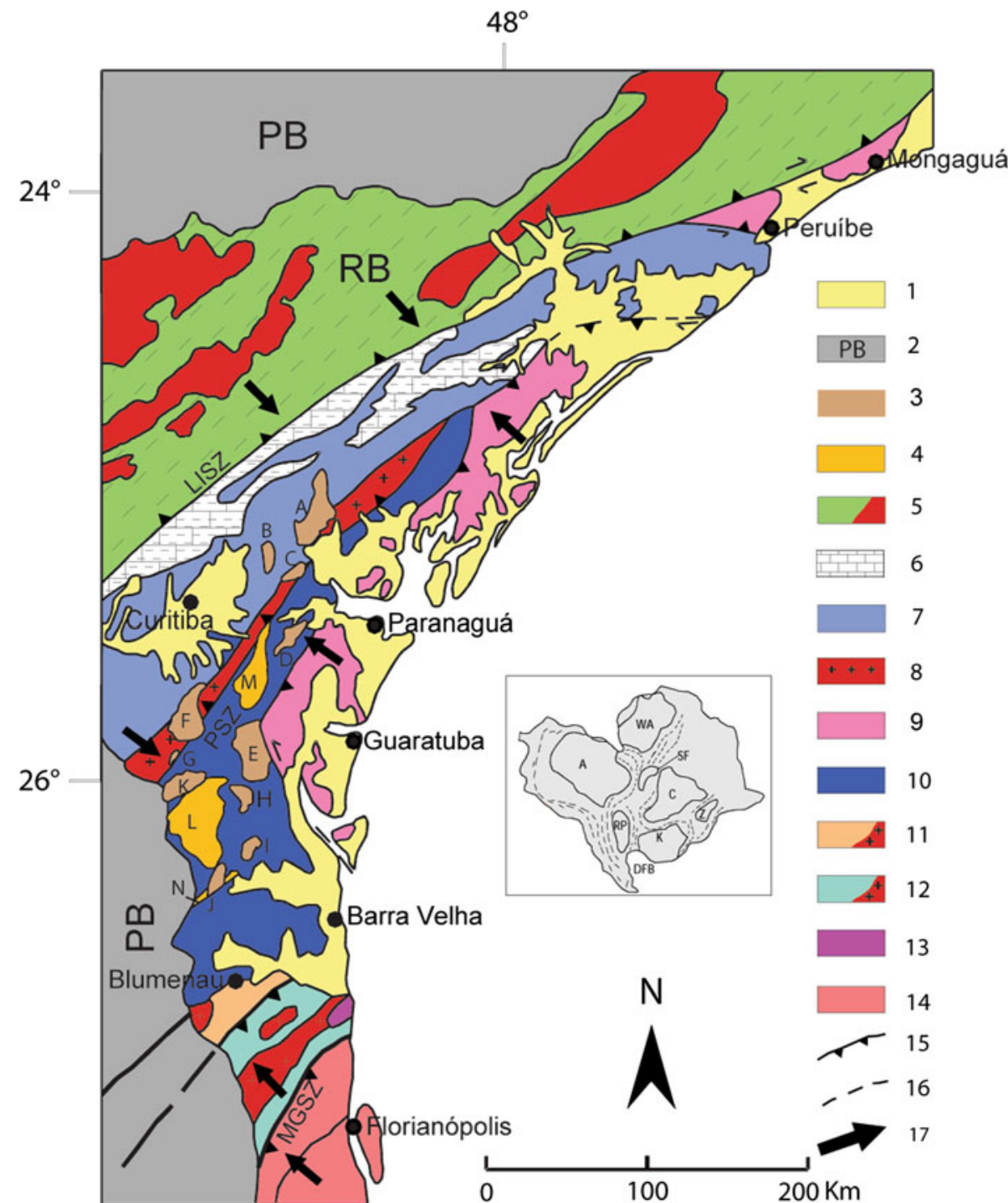

The Florianópolis Batholith is predominantly composed of calc-alkaline to alkaline granitoid rocks and late isotropic alkaline granitoids. It represents the roots of an Ediacaran magmatic arc formed between 620 and $590 \mathrm{Ma}$ as a result of the eastward subduction of an oceanic crust (Adamastor Ocean). The supracrustal rocks related to the Kaoko/Damara/Gariep belts represent the back-arc deposits (Basei 2000; Basei et al. 2005; 2008b). The Brusque Group stretches out in a NE-SW belt of $c a .40 \mathrm{~km}$ in width. It is composed of two metavolcano-sedimentary units separated by the Valsungana Batholith. Metavolcanosedimentary successions predominate and represent the Brusque paleo-basin rift phase. They are characterized by tourmalinites associated with metabasalts, banded iron formations, quartzites and calc-silicate rocks, tectonically overlain by a thick metasedimentary sequence composed of micaceous quartzites, quartz-sericite schists, sericite schists, and local acid metavolcanic rocks. The granitic magmatism is characterized by three isotropic to slightly deformed granitoid suites of metaluminous to peraluminous composition marked by crustal contribution.

\section{The Itajaí Basin}

The Itajaí Basin represents a foreland-type basin of the Dom Feliciano Belt deposited by the end of the Neoproterozoic, between 600 and 560 Ma. It comprises a thick pile of sedimentary rocks with a marked turbiditic contribution and was affected by important felsic volcanic activity (Basei et al. 1998a). It is an asymmetric basin, elongated approximately in the N60E direction and having the shape of a sigmoidal prism, with thickening of sediments from north to south (Rostirolla 1991, Rostirolla et al. 1992). It occupies an area of $c a .700 \mathrm{~km}^{2}$ and extends for more than $80 \mathrm{~km}$ from the coast of Santa Catarina to its 
Fig. 2 Tectonic

compartmentation of the Dom Feliciano Belt (modified after Basei 2000 and Basei et al. 2008a, b, c)

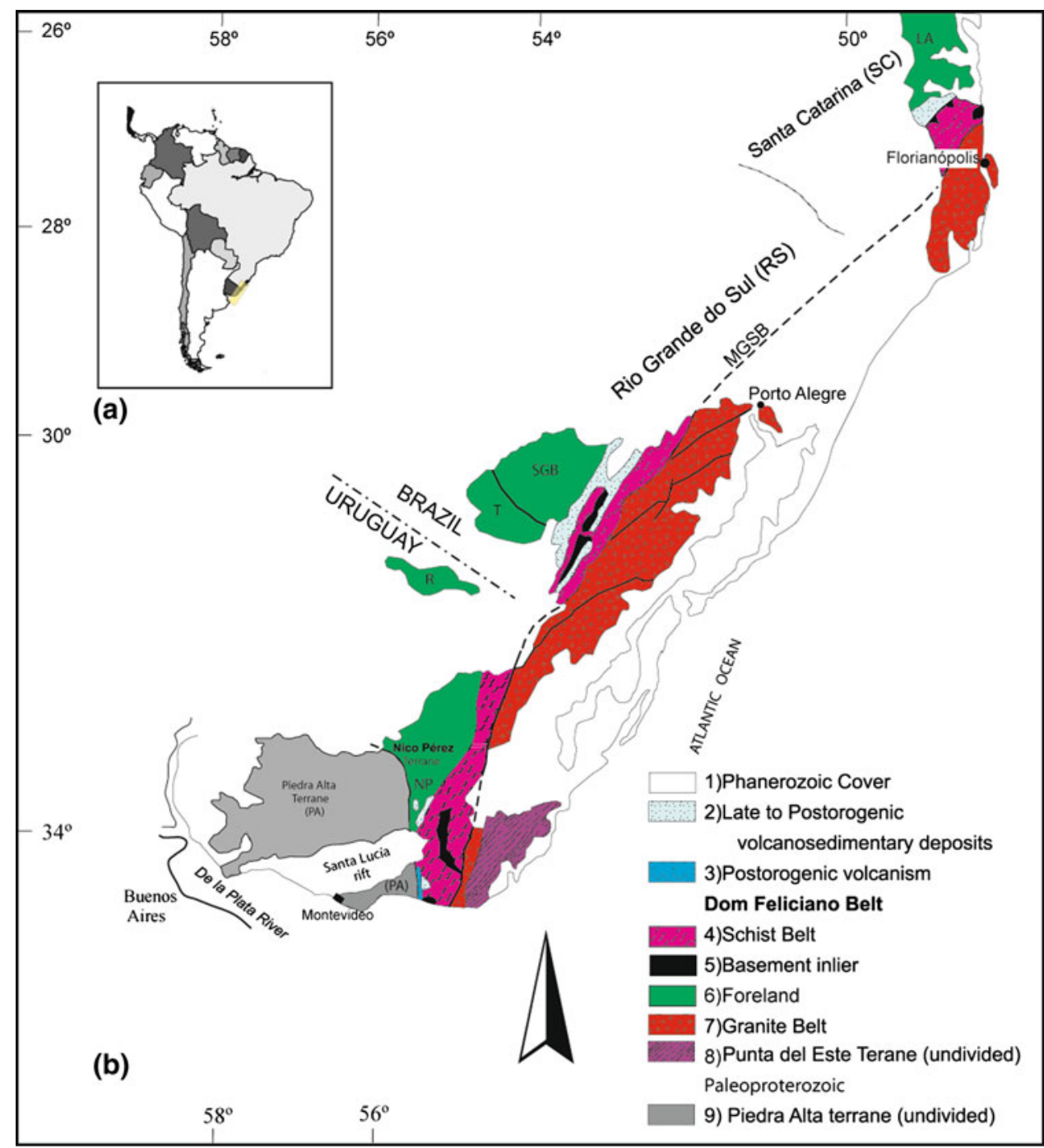

southeastern extremity, covered by the Paraná Basin sediments. The northern and southern limits of the Itajaí Basin are well defined in the field and distinct from one to another. The sediments of the northern border rest on Santa Catarina Granulitic Complex, the Paleoproterozoic basement of Luis Alves Microplate. In contrast, the southern border contact is predominantly tectonic, with the basal units being overthrusted by banded tonalitic-granodioritic gneisses of the São Miguel Complex and by the metavolcano-sedimentary rocks of the Brusque Group.

Studies involving the Itajaí Basin started at the begining of the 20th century with countless works focusing on stratigraphy, such as Carvalho and Pinto (1938), Freitas (1945), Maack (1947) and Salamuni et al. (1961). In this phase, the Itajaí Basin sediments were grouped into two formations and the importance of the conglomerates was recognized. In later studies (Schulz Jr et al. 1970; Kaul 1976; Silva and Dias 1981), the two formations were described in detail and correlated with basins situated to the north, the Campo Alegre Formation being defined in this period. Basei (1985) reiterated the stratigraphic division of the Itajaí Basin into two units. The lower sandy unit, equivalent to the Gaspar Formation, is composed of massive arkosic sandstones, volcanic tuffs, and thick polymictic conglomerates lenses representing proximal fluvial deposits. These are overlain by a rhythmic sandy-silty package formed by alternating silty and sandy layers and conglomeratic sandstone levels, related to proximal turbidites with channelized portions. The upper unit starts with silty-sandy deposits, interpreted as intermediate to distal turbidites. The top sediments are homogeneous, bluish, laminated argillites and siltites, related to distal, diluted turbidity currents associated with the vertical deposition. Applying sequence stratigraphy, Krebs et al. (1988; 1990); Appi (1991); Appi and Cruz (1990); Rostirolla et al. (1992, 1999) and Fonseca (2004) described the sedimentary environments in detail and proposed a series of major sequences divided into several sedimentary facies. Differing from the previous proposal, the last three works propose a third unit, which marks the return of progressively 
more continental depositional systems. Citroni (1993), from the recognition of depositional paleo-environments and their succession, presents a stratigraphic column represented in terms of facies associations, from base to top: Continental Associations, subdivided into interlacing fluvial sandy paleo-environments, followed by rudaceous alluvial fans; Transitional Associations, with shallow-water sandstones, deltaic sandstones, and coastal-plain sandstones; Basinal Associations, with subaqueous sliding deposits followed by hemipelagic deposits; Turbiditic Associations, with diluted turbidites; classic, mediumdensity turbidites; graded, dense turbidites; and sandy to conglomeratic, dense turbidites.

In the tectonic context, by means of structural framework, sedimentation pattern, regional tectonic scenario, and geochronology, several classification proposals were presented for the Itajaí Basin, which can be gathered in two main groups, one of which being the Rift-type Basin (Citroni 1993) or, in a broader sense, Molassic Foredeep, Foreland, Peripheral Foreland (Basei 2000; Basei et al. 2008b; Rostirolla 1991, Rostirolla et al. 1992, 1999;
Guadagnin 2007). In the second group, the mechanism in question is flexural subsidence, related to overload of allochthonous terrains of the Dom Feliciano Belt, tectonically transported NW. Alternatively, Gresse et al. (1996), considering subduction to SW, classifies the Itajaí Basin as a foreland back-arc basin. It is here suggested, in accordance with Dickinson (1974), that the best classification for the Itajaí Basin be "peripheral foreland basin".

\section{The Itajaí Basin lithostratigraphic units}

The geologic map of Fig. 3 is a synthesis of the information collected in the Itajai Basin over the past 20 years. The layout of the five lithostratigraphic units that constitute the Itajai Group results from the deformation (folding and faulting) that affected the Basin. This deformation has always been neglected and consequently its great importance in the present configuration of the basin has not been appreciated. Detailed NW-SE-trending geologic-structural

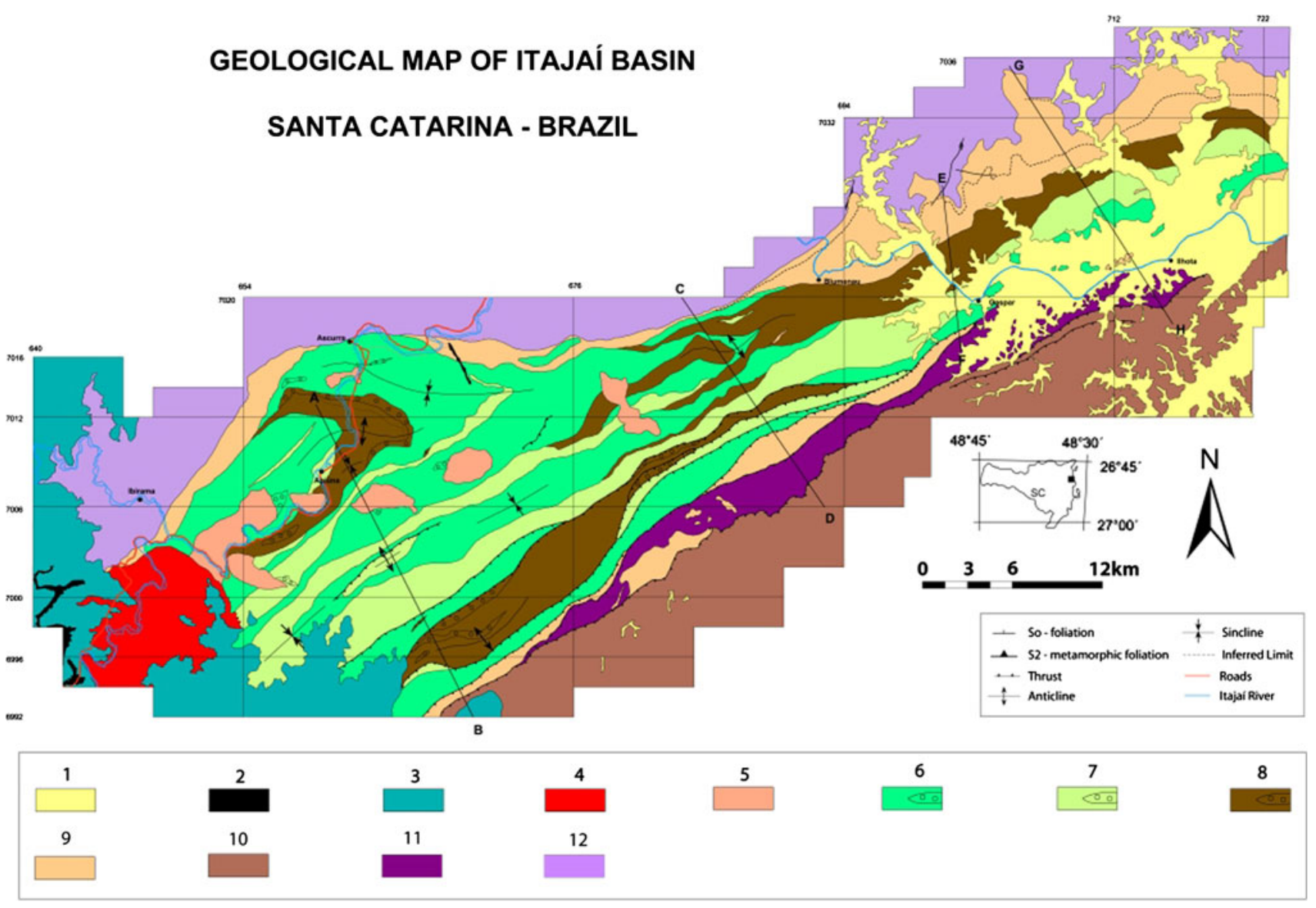

Fig. 3 Geologic map of the Itajaí Basin: 1 Quaternary; 2 Basic sill; 3 Paraná Basin; 4 Cambrian Subida granite; 5 Apiúna volcanics; 6 Ribeirão do Bode Fm; 7 Ribeirão Neisse Fm; 8 Ribeirão Carvalho
Fm; 9 Baú Fm; 10 Brusque Group; 11 São Miguel Complex; 12 Santa Catarina Granulite Complex. The foliation attitudes were excluded for clarity 
Fig. 4 Geologic-structural sections that show the spatial relationships between the mapped units. Same colors as presented in Fig. 3
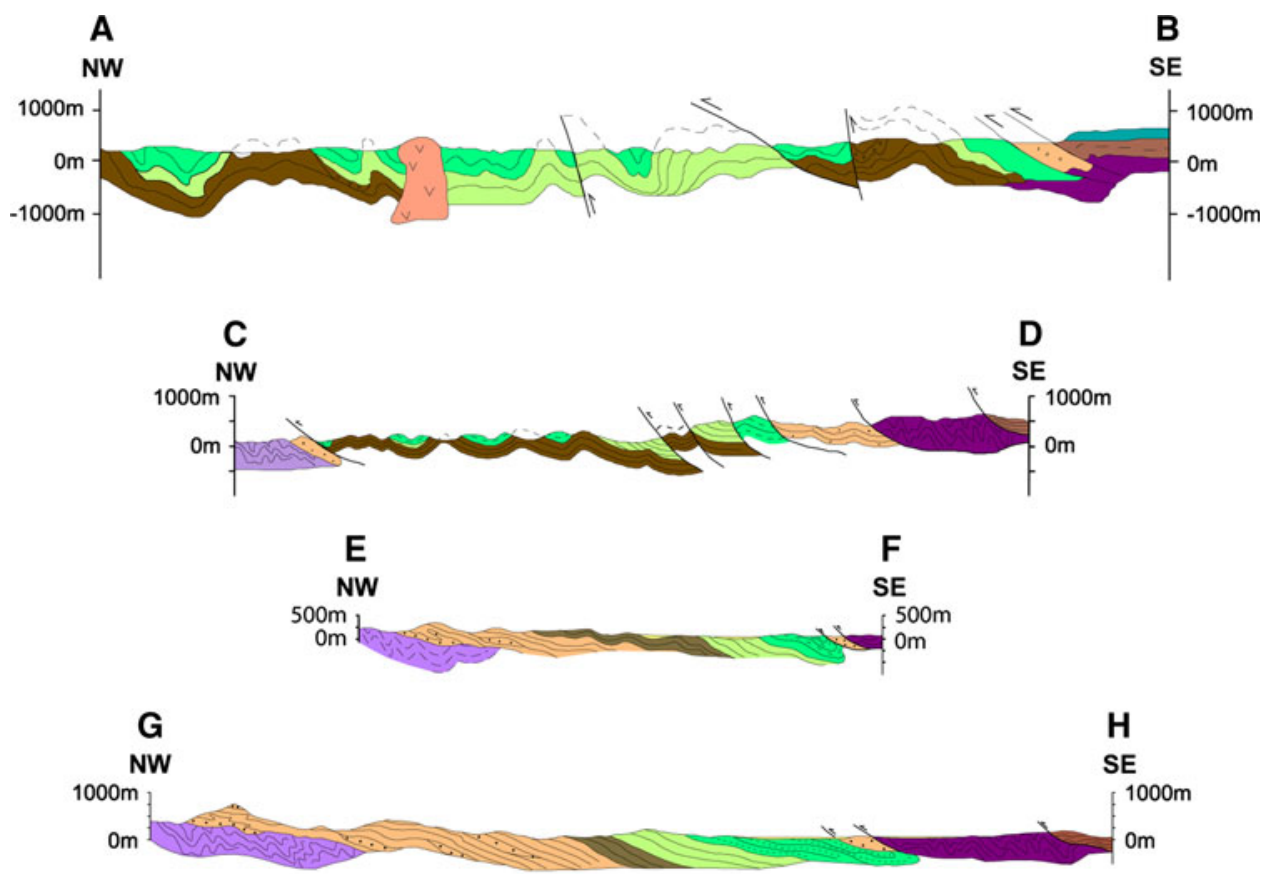

sections (Fig. 4) largely contributed to the definition of the units, of the stratigraphy and to calculate the apparent thickness of each unit. To reach these aims, the surface bedding $\left(S_{0}\right)$ and sedimentary features indicative of top and base were used. One of the main contributions from the geologic map was finding out that the units in the southern border represent the tectonic repetition of the basal units that are better represented in the northern border of the Basin. The proposed stratigraphic sequence must be understood as valid for the Itajaí Basin as a whole. Locally, some of the units described in the complete sequence may be lacking.

The proposed stratigraphic column (Fig. 5) was established from field relationships and the analysis of the spatial behavior of the lithostratigraphic units. From base to top, the complete sequence comprises the Baú Formation, the Ribeirão Carvalho Formation, the Ribeirão Neisse Formation, the Ribeirão do Bode Formation, and the Apiúna Formation.

The continental Baú Formation represents the basal unit and occurs in both borders. It is composed of clast-supported, polymictic conglomerate lenses that extend for hundreds of meters, having a sandy-arkosic matrix. The clasts vary from granules to boulders. They are composed predominantly of gneisses, granites, vein quartz, quartzites, and mylonites (Fig. 6a). Mica-schist clasts and fragments of rock types of the Itajaí Basin itself are volumetrically less important. Toward the top, dark red, micaceous arkosic sandstones tend to predominate (Fig. 6b). They contain sub-angular to sub-rounded grains of moderate sphericity. These rocks are poorly sorted, medium- to coarse-grained or even conglomeratic and can grade to a granule-rich conglomerate. Volcanic tuffs occur intercalated with sandy levels. The primary sedimentary structures are clast imbrication and sigmoidal cross-stratification. Nevertheless, the conglomerates are frequently chaotically organized. The sandy levels form lenticular layers with thickness varying from 0.2 to $1.2 \mathrm{~m}$ and show an internal massive structure or normal graded bedding, plane-parallel stratification, tabular cross-stratification, tangential crossstratification at the base, and low-angle, small, channelized cross-stratification. The estimated thickness of this unit is $1,350 \mathrm{~m}$. The deposition of this pile can be attributed to deltaic fan systems, representing immature, coarse-grained alluvial sediments that entered the basin transversally, the basal conglomeratic level representing the gravelly deltaic plain facies and the upper sandy level representing the proximal deltaic front facies (Fonseca 2004).

Overlying the Baú Formation there occur the rhythmic sediments of the Ribeirão Carvalho Formation. This 650m-thick unit is composed of rhythmites resulting from proximal turbiditic contribution and can be divided into two main rock types: (1) Rhythmites represented by tabular bodies with rippled top and rare erosion features, composed of medium- to fine-grained sandstones intercalated with centimeter- to decimeter-sized layers of shale (Fig. 6c), 
Fig. 5 Itajaí Group lithostratigraphic column, Santa Catarina

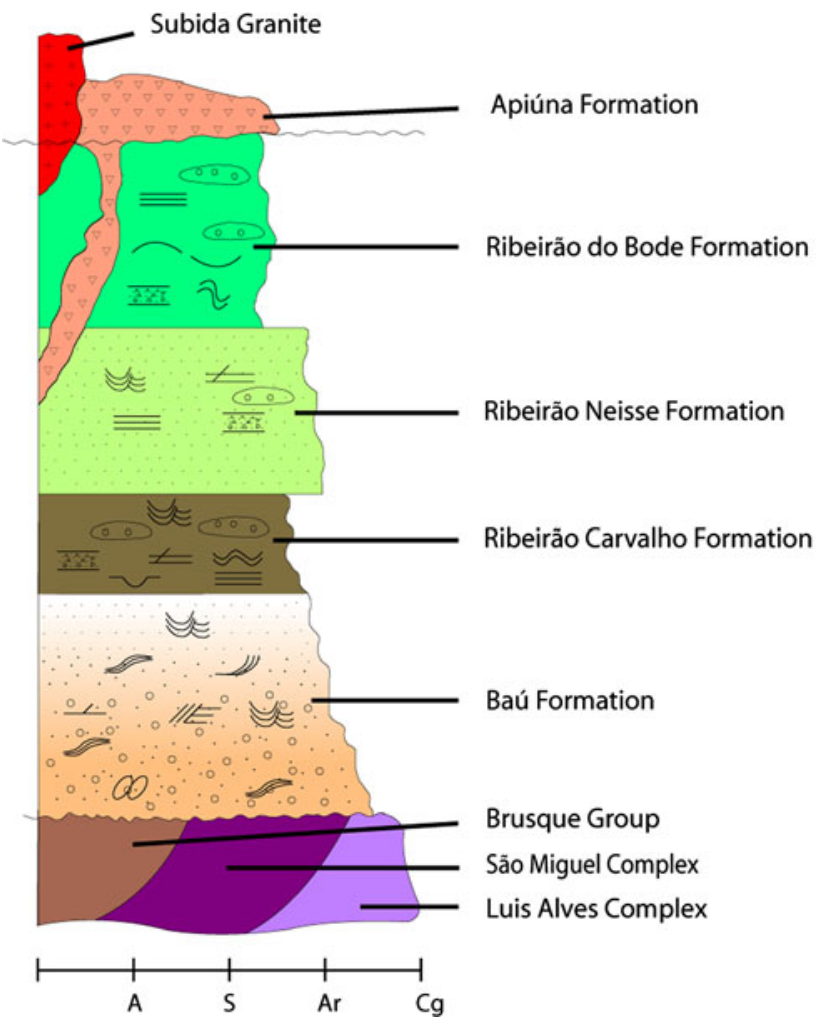

Legend of Primary Structures

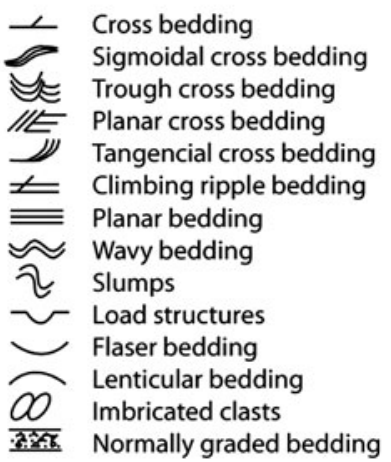

siltites, and thicker, medium-grained sandstones. They present as sedimentary structures the $T_{\mathrm{A}}, T_{\mathrm{B}}, T_{\mathrm{C}}$, and $T_{\mathrm{D}}$ Bouma facies, turboglyphs, and overload structures. The best examples occur close to Apiúna, along the BR-470 highway, and are interpreted as turbiditic lobes and lobe fringes formed under a non-confined regime (Santos et al. 2008); (2) Rhythmites represented by apparently massive, slightly channelized bodies, composed predominantly of medium-sand- to coarse-sand-graded sandstones and thin sandstones intercalated with shale. These rhythmites are interpreted as channelized and lobe-channel transition turbidites (Santos et al. 2008), and are intercalated with polymictic conglomerate levels of massive structure. Locally they exhibit upward-fining and are formed by centimeter- to decimeter-sized angular to sub-angular clasts composed of quartz, milky quartz, fragments of varied Itajaí Basin rock types, and abundant acid volcanic rock clasts.

The rhythmites are overlain and in gradational contact with the 1,000 m-thick Ribeirão Neisse Formation. This formation is composed of immature, poorly sorted, fine- to medium-grained, gray arkosic sandstones, showing planeparallel stratification, climbing-ripple cross-stratification (Fig. 6d), small- and medium-scale channelized crossstratification, and slumps.

The upper Ribeirão do Bode Formation represents the youngest sedimentary unit of the Itajaí Group with estimated thickness of $1,500 \mathrm{~m}$. It is composed of finely laminated siltites alternating with silty-argillaceous layers containing silty-sandy levels (Fig. 6e). Massive siltite levels occur subordinately. The greenish-gray laminated siltites constitute meter-sized layers with plane-parallel lamination, wavy, linsen, slump structures, and graded bedding. Intercalations of polymictic conglomerates with acid volcanics clasts occur associated with this unit.

Completing the lithostratigraphic column, rhyolitic rocks of the Apiúna Formation occur. The Subida leucosyenogranite represents the last magmatic activity to affect the Itajaí Group sediments, the emplacement taking place after the units that constitute the Basin had been deformed (Basei et al. 2008b).

\section{Structural geology}

The deformation pattern observed in the Itajaí Basin is characterized by two main folding phases with distinct axial orientations. The surface bedding $S_{0}$ is the main surface in the whole Basin. Several primary structures can be recognized, which have not been transposed by any foliation generated by the tectonic events that followed sedimentation. On the map of Fig. 7, the stereograms constructed with the attitudes of the bedding poles measured throughout the Itajaí Basin are represented. The dispersion of the foliation $S_{0}$ poles indicate that the basin was affected by two phases of cylindrical folding: the first 
Fig. 6 a Clast-supported conglomerate of the Baú Formation, north of Gaspar. Imbricated clasts of gneisses, granites, vein quartz, quartzites and mylonites; $\mathbf{b}$ arkosic sandstone level in the Baú Formation; c proximal turbiditic rhythmites of the Ribeirão Carvalho Formation alternating medium- to fine-grained sandstones and shale and siltite layers. Ribeirão Carvalho Formation, outcrop along the BR-470 highway, between Ibirama and Apiúna; $\mathbf{d}$ poorly sorted, medium-grained, immature arkosic sandstones with medium-scale crossstratification, Ribeirão Neisse Formation, south of Apiúna; e laminated silty-argillaceous sediments intercalated with decimeter- to meter-sized siltysandy levels, Ribeirão do Bode Formation, south of Apiúna
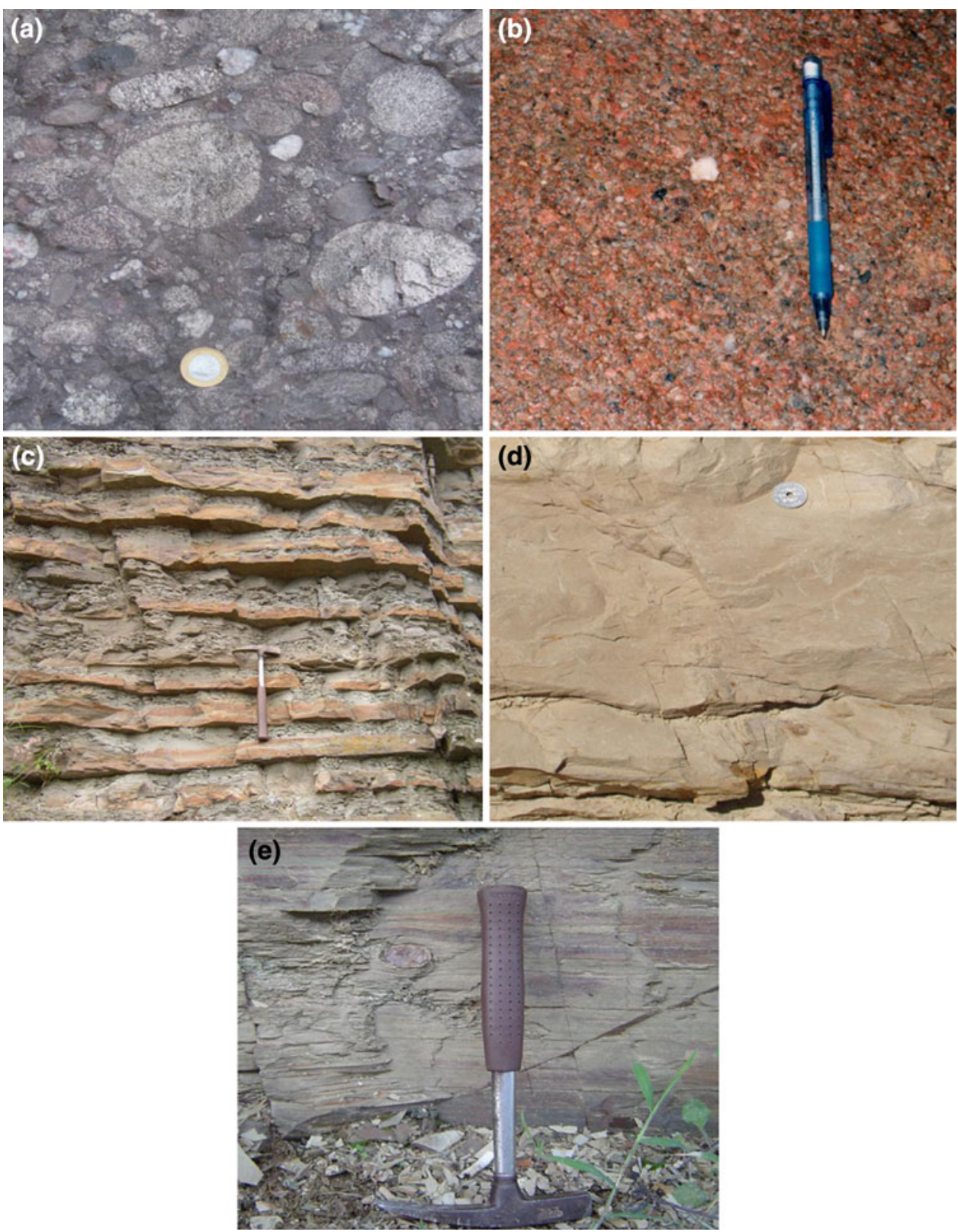

and more intense presents preferential axial orientation between E-W and NE-SW, parallel to the length of the basin; the second strikes approximately $\mathrm{N}-\mathrm{S}$.

The first phase (D1) is the main deformation phase affecting the Itajaí Group as a whole. It is genetically associated with the thrusting that deformed the southern portion of the Basin. It is characterized by cylindrical folds, with axes parallel to the Basin elongation and to the thrusting front, which resulted from the Brusque Group overthrusting the Basin sediments, causing the repetition of the Itajaí Basin basal units in its southern flank.

Figure 8a represents phase D1 folds affecting the bedding $\left(S_{0}\right)$ of the Ribeirão Neisse Formation sandstones, localized in the vicinity of Faxinal da Água Fria.
Cylindrical folds (Fig. 9a) with axial orientation N70E $/ 6^{\circ}$ and $\mathrm{N} 64 \mathrm{E} / 16^{\circ}$ are represented in this figure, the oblique cleavage poles S1 dipping much more strongly to SE, indicating tectonic vergence to NW. Figure $8 \mathrm{~b}$ shows cylindrical folds of the same phase, which were characterized in rhythmites localized close to the Basin southern border. By using the maximum concentration of oblique cleavage S1 (Fig. 9b) data in the same section (Fig. 8c), the preferential vergence of the structures generated by D1 is confirmed to be toward NW. Phase D1 axial orientation can be clearly seen in the NW-SE sections, which are transversal to the Basin long axis. In several places, pencil structures formed by the intersection between the S1 foliation and the $S_{0}$ bedding can be found (Fig. 9c). 


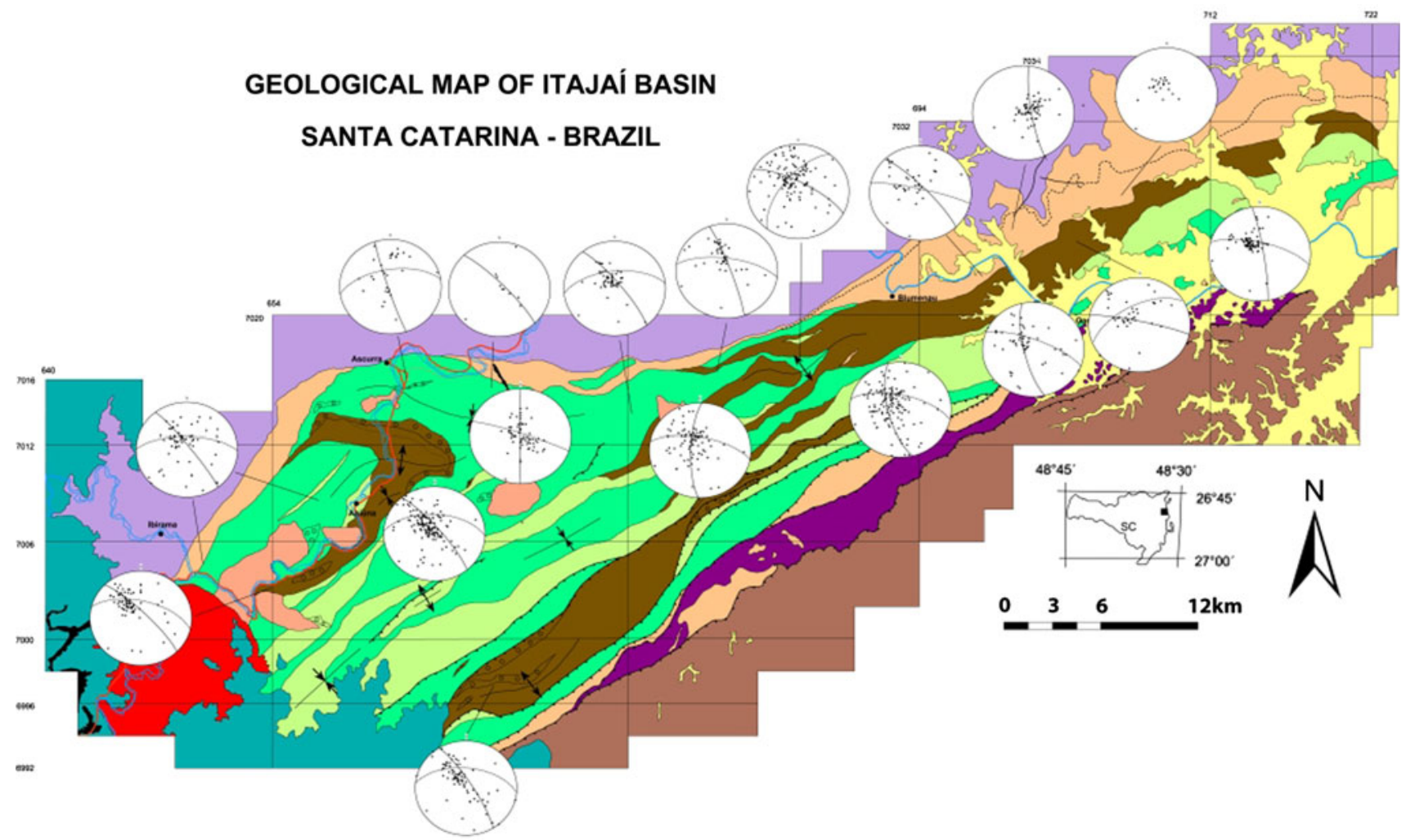

Fig. 7 Stereograms (Schmidt diagrams, lower hemisphere) with attitudes of the poles of the main surface $S_{0}$. Continuous girdles represent phase D1 folds; dashed girdles represent phase D2. The stereograms are drawn close to the areas where the data were collected

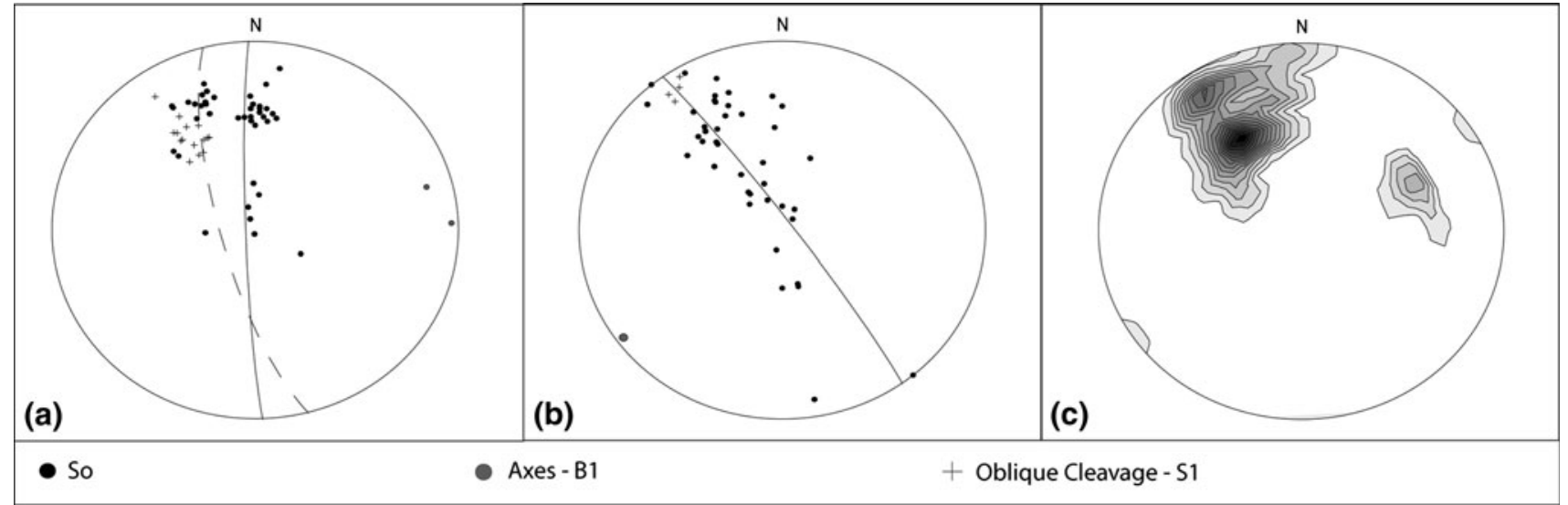

Fig. 8 D1 cylindrical folds in a Ribeirão Neisse Formation sandstones, and b Ribeirão Carvalho Formation rhythmites, representing the Itajaí Group first deformation phase-southern border, close to Faxinal da Água Fria; c oblique cleavage S1 along the Apiúna-

In the section of Fig. 10, phase D1 deformations are characterized by ample and open folds, represented by synforms and antiforms with vertical axial planes in the northern portion, which grade to inverse faults and thrusting close to the southern border of the Itajaí Basin, where the units of the São Miguel Complex and Brusque Group overthrust the Basin younger units. Section CD, located in
Faxinal da Água Fria section (concentrations represented in descending order, from darker to lighter gray; total of 74 data; attitude of the maximum: $\mathrm{N} 50 \mathrm{E} / 42 \mathrm{NW}$ )

the proximity of the Ilhota municipality, and EF, close to the Gaspar municipality (Fig. 4), shows that the changes from one sedimentary unit to another are frequently transitional. For bedding, strikes of ENE-WSW and dips of $15^{\circ}$ to $40^{\circ} \mathrm{SE}$ predominate. In the northern border, the contact between the basal unit sediments and the gneisses of the Luís Alves Microplate basement (Santa Catarina 
Fig. 9 Structural featuresa Crest of phase D1, meter-sized fold, with NE-SW axial orientation. Siltites, south of Blumenau; $\mathbf{b}$ traces of $\mathrm{S} 1$ cleavage surface obliquous to $\mathrm{S} 0$ bedding in laminated siltstone; c pencil structures in siltstones, BR470, near Gaspar; d inverse faults in the conglomerates and Brusque metasediments, southern Itajaí border; e Sc/Ss relationship associated with fault movement parallelal to bedding plane with top displacement to NNW Laminated siltites, Ribeirão do Bode Formation, South of Apiúna developed by $\mathrm{S} 1 / \mathrm{S} 0$ interaction contact between Itajaí (right-hand side of the photo).
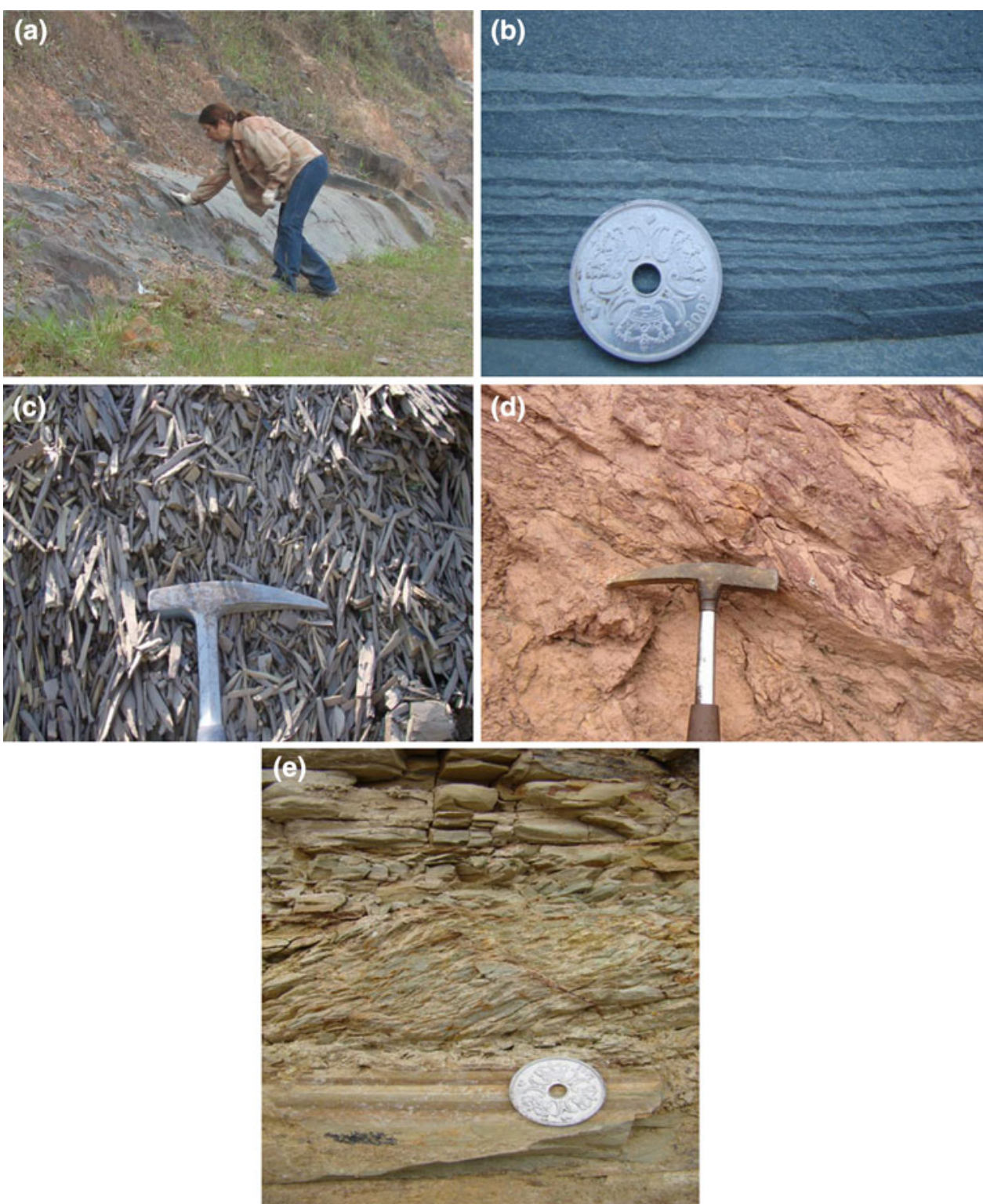

Fig. 10 Geologic section between Apiúna $(N W)$ and Faxinal da Água Fria (SE). Stereographic projections (Schmidt-Lambert diagrams, lower hemisphere) of surface $S_{0}$ for each unit. The colors for each unit correspond to those of the geologic map

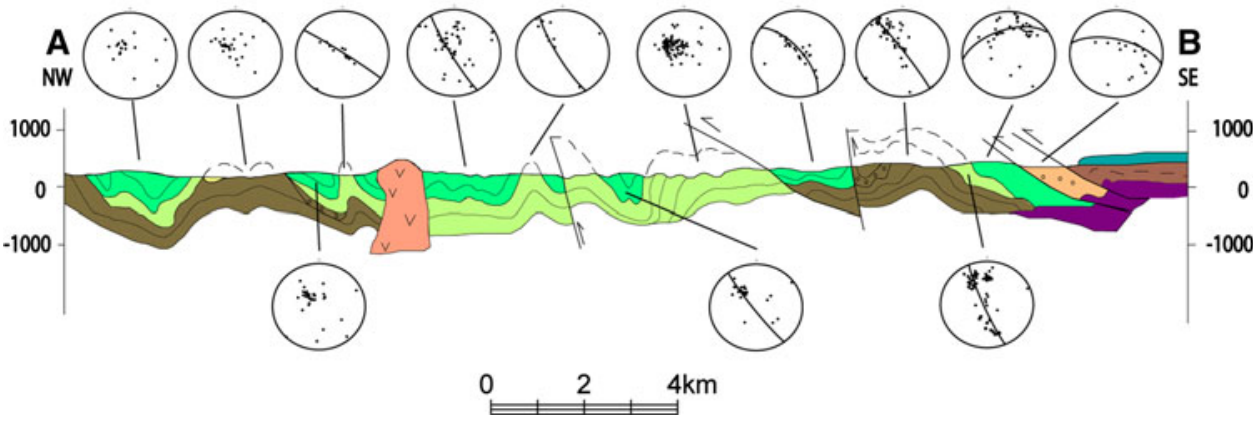

Granulitic Complex) is normal, whereas in the southern portion, the contact with the Brusque Group and the São Miguel Complex is tectonic by inverse faulting (Fig. 9d). Here, the basement overthrusts the Basin sedimentary units and stratigraphic inversion also occurs, as seen between Apiúna and Faxinal da Água Fria (sections a, b and c, d in Fig. 4). The amount and importance of the displacements related to the thrusts are hidden, in many cases, by shear planes parallel to the bedding surfaces (Fig. 9e). 
Fig. 11 Schmidt stereonet, lower hemisphere, demonstrating D2 folding and its overprint on D1. a Ribeirão Neisse Formation, south of Apiúna, and b Ribeirão do Bode Formation siltites, close to Faxinal da Água Fria

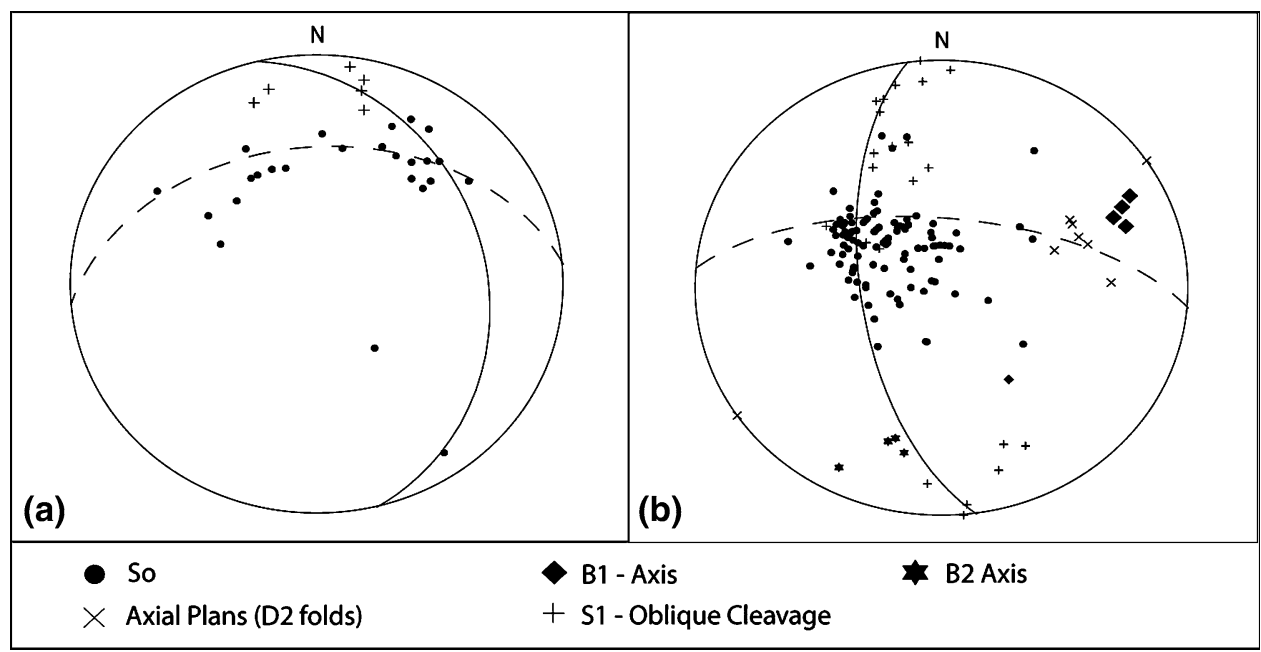

The second deformation phase D2 is represented by ample and discontinuous folds of large wavelength and approximately $\mathrm{N}-\mathrm{S}$ axial orientation, in general plunging slightly southward. The stereogram of Fig. 11a, constructed with structural data for the Ribeirão Neisse Formation south of Apiúna, shows the interference of phase D2 (dashed girdle) on phase D1. This second folding of axial orientation $\mathrm{S} 5 \mathrm{~W} / 25^{\circ}$ causes a dispersion both of bedding poles, represented by approximately $\mathrm{N}-\mathrm{S}$-trending layers, and the attitudes of the oblique cleavage $\mathrm{S} 1$ poles. The same interference pattern is seen in Fig. 11b, constructed with data from the Ribeirão do Bode Formation siltites, from near Faxinal da Água Fria. Phase D2 axis strikes $\mathrm{S} 5 \mathrm{E} / 50^{\circ}$, causing strong dispersion of bedding poles and of cleavage $\mathrm{S} 1$.

The comparison between the deformations recognized in the Itajaí Basin sediments and in the Brusque Group leads to the correlation of the two deformation phases in the Itajaí Basin, respectively, with the Brusque Group deformational phases D4 and D5, which affected it after the metamorphic peak (Basei 1985).

\section{Lithogeochemistry}

The geochemical study of the sedimentary rocks was carried out using 23 samples (Table 1) collected along three sections traversing the Itajaí Group units. This study aimed at understanding the variabilities between different Itajaí Basin lithostratigraphic units. The chemical composition of the terranes that acted as source areas of the Itajaí Basin sediments is probably the major controller of the geochemical signature of the Basin rocks (Rollinson 1993).

The diagram in Fig. 12a was used to classify the samples into major sandstone classes, the $\mathrm{SiO}_{2} / \mathrm{Al}_{2} \mathrm{O}_{3}$ ratio serving to distinguish quartz-rich sandstones from Al-rich sandstones, and the $\mathrm{Na}_{2} \mathrm{O} / \mathrm{K}_{2} \mathrm{O}$ ratio to distinguish wackes from arkoses (Pettijohn et al. 1972). In this diagram, the sandstones from the Baú Formation and the Ribeirão do Bode Formation are classified as arkoses, lithic sandstones and wackes, whereas the sandstones from the Ribeirão Carvalho and Ribeirão Neisse Formations are characterized as lithic sandstones. This classification is maintained in the diagram involving $\mathrm{Fe}_{2} \mathrm{O}_{3}+\mathrm{MgO}, \mathrm{Na}_{2} \mathrm{O}$ and $\mathrm{K}_{2} \mathrm{O}$ contents (Fig. 12b), except for the sandstones of the São Pedro and Ribeirão Neisse Formations, which plot in the arkose field. According to Fig. 12c, practically all samples plot on or above the $\mathrm{Na}_{2} \mathrm{O} / \mathrm{K}_{2} \mathrm{O}=1$ line, indicating that they are quartz-rich. In Fig. $12 \mathrm{~d}$ the $\mathrm{SiO}_{2} / \mathrm{Al}_{2} \mathrm{O}_{3}$ ratio is used not only to distinguish quartz-rich sediments, wackes, and argillites but also to evaluate mineralogical maturity (Pettijohn et al. 1972). In turn, the $\mathrm{Fe}_{2} \mathrm{O}_{3} / \mathrm{K}_{2} \mathrm{O}$ ratio is very useful to distinguish lithic feldspathic fragments present in sandstones. It is possible then to classify with this diagram the sediments of the Baú Formation as predominantly wackes; the sediments of the Ribeirão Carvalho and Ribeirão Neisse formations as arkoses and shale, and the sediments of the Ribeirão do Bode Formation as predominantly shale with subordinate arkoses and wackes. It was also possible to characterize all the Itajaí Basin sediments as mineralogically immature.

The "spidergrams" constructed using chondrite-normalized REE contents (McLennan and Taylor 1985) reveal a gradual increase in negative Eu anomaly and decrease in HREE fractionation from base to top. As can be seen in Fig. 13, the spidergram corresponding to the basal Baú Formation differs from those corresponding to the upper units. It shows a slight negative Eu anomaly, when compared to the intermediate values for the Ribeirão Carvalho and Ribeirão Neisse Formations and to the high values for the Ribeirão do Bode Formation. The Baú Formation decreases in the Ribeirão Carvalhos and Ribeirão Neisse Formations and is the weakest in the Ribeirão do Bode shows the strongest HREE fractionation, which gradually 
Table 1 WR geochemical data (major, trace and rare-earth elements)

\begin{tabular}{|c|c|c|c|c|c|c|c|c|c|c|c|}
\hline & IA-01 & IA-02 & IA-03 & IA-08 & IA-09A & IA-09C & IG-01 & IG-02 & IG-04a & IG-05B & IG-06B \\
\hline $\mathrm{SiO}_{2}$ & 76.2300 & 78.1200 & 72.8600 & 62.5100 & 64.1000 & 63.5200 & 69.3200 & 61.5600 & 60.9800 & 62.8400 & 63.4600 \\
\hline $\mathrm{Al}_{2} \mathrm{O}_{3}$ & 12.3200 & 10.7400 & 12.8600 & 17.8600 & 16.2600 & 17.2500 & 13.9000 & 17.9000 & 17.7900 & 17.7000 & 16.9500 \\
\hline $\mathrm{MnO}$ & 0.0590 & 0.0830 & 0.0420 & 0.0630 & 0.0730 & 0.0630 & 0.0400 & 0.0950 & 1680 & 0.0900 & 1050 \\
\hline $\mathrm{MgO}$ & 0.2300 & 0.4400 & 0.5200 & 5900 & 2.3000 & 2.2800 & 1.1600 & 00 & 200 & 00 & 400 \\
\hline $\mathrm{CaO}$ & 0.0800 & 0.4100 & 0.8000 & 0.8900 & 0.3600 & 0.2900 & 1.6500 & 0.1100 & 0900 & 1.3000 & 0.6900 \\
\hline $\mathrm{Na}_{2} \mathrm{O}$ & 3.6900 & 2.2900 & 2.0500 & 1.4000 & 2.4000 & 2.2400 & 3.0900 & 0.9900 & 8900 & 2.3700 & 8500 \\
\hline $\mathrm{K}_{2} \mathrm{O}$ & 3.0500 & 3.4700 & 4.3700 & 4.8700 & 3.5700 & 4.1100 & 2.9800 & 5.0600 & 4.9900 & 4.3000 & 4.3000 \\
\hline $\mathrm{TiO}_{2}$ & 0.3050 & 0.3240 & 0.5240 & 0.8640 & 0.8020 & 0.8180 & 0.4880 & 0.9980 & 0.9210 & 0.8420 & 0.7210 \\
\hline $\mathrm{P}_{2} \mathrm{O}_{5}$ & 0.0240 & 0.0710 & 0.1070 & 0.1570 & 0.1720 & 0.1450 & 0.1140 & 0.0360 & 0.0260 & 0.1680 & 0.1550 \\
\hline $\mathrm{Fe}_{2} \mathrm{O}_{3}$ & 2.4400 & 2.1400 & 2.6600 & 5.6700 & 6.5000 & 5.9000 & 3.7200 & 7.4200 & 7.7700 & 5.9100 & 6.3300 \\
\hline Loi & 1.1800 & 1.4200 & 2.4800 & 3.7900 & 3.0300 & 3.1000 & 3.0600 & 3.3600 & 3.8400 & 1.9400 & 3.0600 \\
\hline Total & 99.6080 & 99.5080 & 99.2730 & 99.6640 & 99.5670 & 99.7160 & 99.5220 & 99.4090 & 99.4850 & 99.4200 & 99.6610 \\
\hline $\mathrm{Ba}$ & 514.4000 & 575.3000 & 586.5000 & 470.8000 & 625.7000 & 618.5000 & 993.0000 & 1266.4000 & 884.5000 & 800.1000 & 576.5000 \\
\hline $\mathrm{Ce}$ & 65.0000 & 56.4000 & 89.3000 & 106.6000 & 90.5000 & 88.5000 & 81.1000 & 76.2000 & 89.8000 & 91.7000 & 92.6000 \\
\hline $\mathrm{Cl}$ & $<50$ & $<50$ & $<50$ & $<50$ & $<50$ & $<50$ & $<50$ & $<50$ & $<50$ & $<50$ & $<50$ \\
\hline Co & 52.3000 & 63.0000 & 37.7000 & 25.1000 & 22.8000 & 18.8000 & 33.9000 & 25.5000 & 25.6000 & 22.0000 & 23.9000 \\
\hline $\mathrm{Cr}$ & 26.3000 & 24.0000 & 29.3000 & 64.5000 & 76.7000 & 80.5000 & 98.6000 & 75.5000 & 95.5000 & 84.7000 & 75.3000 \\
\hline $\mathrm{Cu}$ & 18.2000 & 8.9000 & $<5$ & 30.1000 & 23.2000 & 5.4000 & 10.4000 & $<5$ & 18.6000 & 23.7000 & 31.3000 \\
\hline $\mathrm{F}$ & $<550$ & $<550$ & 844.8000 & 1362.4000 & 1537.7000 & 1459.6000 & $<550$ & 967.3000 & 929.8000 & 1091.0000 & 1210.9000 \\
\hline $\mathrm{Ga}$ & 16.2000 & 13.8000 & 17.8000 & 27.1000 & 21.7000 & 24.3000 & 17.2000 & 25.0000 & 27.9000 & 25.5000 & 24.8000 \\
\hline $\mathrm{La}$ & 29.3000 & 35.5000 & 50.7000 & 55.8000 & 39.1000 & 37.5000 & 46.1000 & 56.1000 & 40.6000 & 54.1000 & 41.4000 \\
\hline $\mathrm{Nb}$ & 26.3000 & 23.1000 & 25.4000 & 26.4000 & 16.8000 & 16.6000 & 17.9000 & 21.5000 & 18.6000 & 23.5000 & 21.2000 \\
\hline $\mathrm{Nd}$ & 39.9000 & 26.7000 & 41.7000 & 56.7000 & 49.6000 & 56.8000 & 36.6000 & 58.8000 & 61.1000 & 57.8000 & 48.6000 \\
\hline $\mathrm{Ni}$ & 9.7000 & 10.9000 & 11.4000 & 28.5000 & 36.2000 & 35.3000 & 31.6000 & 37.0000 & 40.0000 & 35.4000 & 42.4000 \\
\hline $\mathrm{Pb}$ & 25.7000 & 29.5000 & 32.6000 & 22.6000 & 12.4000 & 4.6000 & 16.5000 & 12.1000 & 32.7000 & 18.0000 & 18.5000 \\
\hline $\mathrm{Rb}$ & 160.9000 & 155.5000 & 204.3000 & 251.3000 & 179.4000 & 198.8000 & 70.7000 & 234.9000 & 246.7000 & 210.5000 & 215.5000 \\
\hline$S$ & $<300$ & $<300$ & $<300$ & $<300$ & $<300$ & $<300$ & $<300$ & $<300$ & $<300$ & $<300$ & $<300$ \\
\hline $\mathrm{Sc}$ & $<14$ & $<14$ & $<14$ & 17.8000 & 16.3000 & 15.7000 & $<14$ & 17.7000 & 17.7000 & 16.8000 & 14.4000 \\
\hline $\mathrm{Sr}$ & 85.1000 & 142.4000 & 149.1000 & 65.8000 & 75.7000 & 63.1000 & 368.1000 & 89.2000 & 50.1000 & 180.0000 & 124.8000 \\
\hline Th & 20.8000 & 16.2000 & 25.4000 & 27.6000 & 12.7000 & 16.3000 & 15.8000 & 19.1000 & 16.4000 & 18.1000 & 12.7000 \\
\hline $\mathrm{U}$ & 13.5000 & 12.4000 & 12.4000 & 13.7000 & 13.7000 & 15.8000 & 6.8000 & 16.1000 & 17.3000 & 11.6000 & 13.0000 \\
\hline V & 25.8000 & 31.8000 & 41.0000 & 90.0000 & 103.1000 & 123.5000 & 63.1000 & 93.2000 & 83.2000 & 101.8000 & 84.6000 \\
\hline $\mathrm{Y}$ & 45.6000 & 26.6000 & 38.6000 & 48.4000 & 38.0000 & 36.1000 & 17.7000 & 44.1000 & 38.2000 & 48.2000 & 37.9000 \\
\hline $\mathrm{Zn}$ & 62.1000 & 37.7000 & 48.5000 & 99.1000 & 113.1000 & 100.0000 & 37.8000 & 86.2000 & 101.2000 & 99.4000 & 121.1000 \\
\hline $\mathrm{Zr}$ & 184.6000 & 172.6000 & 358.9000 & 280.3000 & 214.3000 & 178.8000 & 179.0000 & 271.1000 & 221.5000 & 247.1000 & 213.4000 \\
\hline Sm & 7.1946 & 5.8621 & 10.0652 & 10.1051 & 7.3379 & 6.3941 & 50 & 7.0130 & 55 & 8.7093 & 6.7026 \\
\hline \multirow[t]{2}{*}{$\mathrm{Hf}$} & 6.7319 & 4.6484 & 10.7984 & 9.0700 & 6.5983 & 5.6438 & 5.3940 & 8.4414 & 6.9247 & 7.2027 & 6.3209 \\
\hline & IG-07 & CTI-01 & CTI-03 & CTI-06 & CTI-08 & CTI-12A & CTI-18A & CTI-22 & 28 & $29 A$ & -37 \\
\hline $\mathrm{SiO}_{2}$ & 71.1300 & 62.9800 & 63.7100 & 8600 & 72.2300 & 200 & 00 & 00 & 00 & 00 & 400 \\
\hline $\mathrm{Al}_{2} \mathrm{O}_{3}$ & 14.8300 & 17.6000 & 16.7600 & 17.3000 & 12.7200 & 17.3600 & 16.1600 & 14.1300 & 17.4700 & 13.8200 & 15.6500 \\
\hline $\mathrm{MnO}$ & 0.0540 & 0.0070 & 0.0400 & 0.0600 & 0.0500 & 0.0400 & 0.0400 & 0.0400 & 0.0900 & 0.0700 & 0.1100 \\
\hline $\mathrm{MgO}$ & 1.1800 & 1.6400 & 1.9900 & 1.8000 & 1.0700 & 1.6100 & 0.6800 & 0.3500 & 2.1600 & 1.3600 & 2.0000 \\
\hline $\mathrm{CaO}$ & 0.4400 & 0.2100 & 0.3700 & 1.0000 & 1.0800 & 0.3400 & 0.1700 & 0.3800 & 0.4400 & 0.3300 & 0.8900 \\
\hline $\mathrm{Na}_{2} \mathrm{O}$ & 1.9000 & 1.6400 & 1.9100 & 1.4200 & 2.6200 & 1.9300 & 1.5100 & 3.4500 & 1.8600 & 2.7500 & 2.4500 \\
\hline $\mathrm{K}_{2} \mathrm{O}$ & 5.1700 & 4.6300 & 3.9600 & 4.8900 & 3.8000 & 4.6200 & 5.6700 & 3.5400 & 4.3500 & 4.2300 & 3.3000 \\
\hline $\mathrm{TiO}_{2}$ & 0.2860 & 0.6900 & 0.7100 & 0.8400 & 0.5600 & 0.7800 & 0.5000 & 0.3300 & 0.8000 & 0.4400 & 0.7800 \\
\hline $\mathrm{P}_{2} \mathrm{O}_{5}$ & 0.0370 & 0.1100 & 0.1300 & 0.1800 & 0.1400 & 0.1500 & 0.0800 & 0.0700 & 0.1500 & 0.0900 & 0.1600 \\
\hline
\end{tabular}


Table 1 continued

\begin{tabular}{|c|c|c|c|c|c|c|c|c|c|c|c|}
\hline & IG-07 & CTI-01 & CTI-03 & CTI-06 & CTI-08 & CTI-12A & CTI-18A & CTI-22 & CTI-28 & CTI-29A & CTI-37 \\
\hline $\mathrm{Fe}_{2} \mathrm{O}_{3}$ & 2.2800 & 5.3800 & 5.7900 & 6.0900 & 3.4100 & 5.4000 & 3.9400 & 2.7300 & 6.2800 & 3.5300 & 6.0200 \\
\hline Loi & 2.1800 & 4.7000 & 4.4000 & 4.3000 & 2.0000 & 3.9000 & 3.7000 & 2.3000 & 3.3000 & 2.4000 & 3.4000 \\
\hline Total & 99.4870 & 99.5870 & 99.7700 & 99.7400 & 99.6800 & 99.7500 & 99.7700 & 99.7600 & 99.7200 & 99.7500 & 99.7000 \\
\hline $\mathrm{Ba}$ & 446.7000 & 1045.0000 & 558.0000 & 593.0000 & 656.0000 & 606.0000 & 741.0000 & 650.0000 & 620.0000 & 866.0000 & 610.0000 \\
\hline $\mathrm{Ce}$ & 46.2000 & 90.2000 & 79.4000 & 92.1000 & 84.9000 & 128.5000 & 92.8000 & 84.8000 & 100.5000 & 71.6000 & 92.1000 \\
\hline $\mathrm{Cl}$ & $<50$ & & & & & & & & & & \\
\hline Co & 17.2000 & 49.8000 & 29.8000 & 24.3000 & 98.4000 & 27.2000 & 23.5000 & 38.4000 & 22.8000 & 59.3000 & 23.2000 \\
\hline $\mathrm{Cr}$ & 16.5000 & & & & & & & & & & \\
\hline $\mathrm{Cu}$ & 8.9000 & 24.4000 & 18.0000 & 30.2000 & 119.8000 & 22.8000 & 11.0000 & 5.0000 & 22.7000 & 4.1000 & 28.1000 \\
\hline F & 1526.5000 & & & & & & & & & & \\
\hline $\mathrm{Ga}$ & 23.6000 & 25.4000 & 22.1000 & 23.2000 & 17.0000 & 25.6000 & 22.9000 & 19.4000 & 23.7000 & 16.9000 & 20.4000 \\
\hline $\mathrm{La}$ & 27.8000 & 38.6000 & 36.7000 & 40.6000 & 38.1000 & 58.3000 & 55.7000 & 36.6000 & 46.6000 & 34.0000 & 42.5000 \\
\hline $\mathrm{Nb}$ & 29.2000 & 19.7000 & 19.4000 & 23.8000 & 25.5000 & 23.8000 & 27.0000 & 24.9000 & 20.1000 & 16.1000 & 20.2000 \\
\hline $\mathrm{Nd}$ & 30.3000 & 38.1000 & 35.8000 & 44.8000 & 36.7000 & 55.5000 & 61.3000 & 41.9000 & 45.5000 & 26.5000 & 39.4000 \\
\hline $\mathrm{Ni}$ & 7.2000 & 67.4000 & 33.0000 & 34.1000 & 20.1000 & 25.6000 & 12.5000 & 23.2000 & 42.8000 & 32.2000 & 35.5000 \\
\hline $\mathrm{Pb}$ & 9.0000 & 11.4000 & 10.2000 & 17.8000 & 13.4000 & 8.5000 & 9.2000 & 13.9000 & 5.0000 & 8.6000 & 25.5000 \\
\hline $\mathrm{Rb}$ & 299.7000 & 246.1000 & 205.9000 & 267.1000 & 176.3000 & 256.1000 & 327.3000 & 192.8000 & 206.5000 & 175.4000 & 174.3000 \\
\hline S & $<300$ & & & & & & & & & & \\
\hline $\mathrm{Sc}$ & $<14$ & 16.0000 & 15.0000 & 16.0000 & 10.0000 & 15.0000 & 12.0000 & 7.0000 & 17.0000 & 8.0000 & 14.0000 \\
\hline $\mathrm{Sr}$ & 57.4000 & 76.2000 & 73.4000 & 83.1000 & 157.2000 & 84.4000 & 87.5000 & 89.4000 & 84.1000 & 187.1000 & 164.7000 \\
\hline Th & 33.5000 & 15.1000 & 15.8000 & 25.9000 & 18.4000 & 19.2000 & 22.9000 & 23.0000 & 19.0000 & 10.5000 & 18.6000 \\
\hline $\mathrm{U}$ & 17.6000 & 3.5000 & 3.4000 & 5.9000 & 3.9000 & 5.1000 & 6.8000 & 5.1000 & 4.7000 & 1.5000 & 3.7000 \\
\hline V & 19.4000 & 104.0000 & 96.0000 & 102.0000 & 66.0000 & 102.0000 & 58.0000 & 35.0000 & 112.0000 & 55.0000 & 91.0000 \\
\hline Y & 52.5000 & 43.6000 & 29.3000 & 46.1000 & 24.7000 & 41.9000 & 70.9000 & 52.6000 & 36.0000 & 15.4000 & 33.8000 \\
\hline $\mathrm{Zn}$ & 83.1000 & 130.0000 & 86.0000 & 83.0000 & 42.0000 & 86.0000 & 100.0000 & 40.0000 & 86.0000 & 45.0000 & 90.0000 \\
\hline $\mathrm{Zr}$ & 190.4000 & 155.1000 & 164.6000 & 248.4000 & 264.3000 & 221.9000 & 195.8000 & 194.9000 & 192.2000 & 143.2000 & 245.9000 \\
\hline $\mathrm{Sm}$ & 8.4271 & 7.1200 & 6.4700 & 9.0300 & 6.5600 & 9.7900 & 13.3300 & 9.5700 & 8.2700 & 4.0500 & 7.2900 \\
\hline $\mathrm{Hf}$ & 7.6535 & 4.7000 & 5.0000 & 7.6000 & 7.5000 & 6.5000 & 6.3000 & 7.5000 & 6.0000 & 4.3000 & 7.1000 \\
\hline
\end{tabular}

Formation. The lithogeochemical pattern yielded by the Baú Formation is similar to that obtained by Basei et al. (1998b) for Luís Alves Microplate basement rocks.

\section{Provenance of the sediments inferred from the lithogeochemical data}

First and foremost, the available geochemical data were treated in order to identify the possible sources of sediments for the Itajaí Basin. Even considering the limitations inherent to this approach, e.g. materials coming from tectonically distinct settings yielding geochemically similar products (McLennan et al. 1990), our study allowed the definition of several parameters to characterize source areas for the Itajaí Group sediments.

Taking into account that Th has affinity with differentiated continental crustal rocks (Faure 2005) and Sc is abundant in the mantle, $\mathrm{Th} / \mathrm{Sc}$ ratios higher than 1 reveal a contribution of upper crustal rocks as source areas
(Fig. 14a), favoring tectonic settings associated with continental collision, passive margins, and magmatic arcs. In Fig. $14 \mathrm{~b}\left(\mathrm{SiO}_{2} / \mathrm{Al}_{2} \mathrm{O}_{3}\right.$ vs. $\mathrm{K}_{2} \mathrm{O} / \mathrm{Na}_{2} \mathrm{O}$ diagram $)$, the preferential involvement of passive margin, continental collision, and subordinately magmatic arc settings is also indicated. In this diagram, the field related to continental collision is the one that best matches with the data corresponding to the upper sequences of the Itajaí Basin, whereas the data corresponding to the basal units are closest to the field related to the passive margin setting.

The relationship between $\mathrm{La} / \mathrm{Th}$ ratios and Hf contents (Fig. 14c) indicates for all the basin units an origin related to a magmatic arc setting with important contribution of sediments associated with a passive margin setting. This suggestion is possible because, due to the low $\mathrm{La} / \mathrm{Th}$ ratios yielded by the Basin sediments, which indicate Th enrichment in relation to $\mathrm{La}$, a provenance from the erosion of upper crustal rocks can be suggested (Floyd and Leveridge 1987).

The comparison between present $\varepsilon_{\mathrm{Nd}}$ values and $\mathrm{Th} / \mathrm{Sc}$ ratios (Fig. 14d) indicates that the source area for the Baú 
(a)

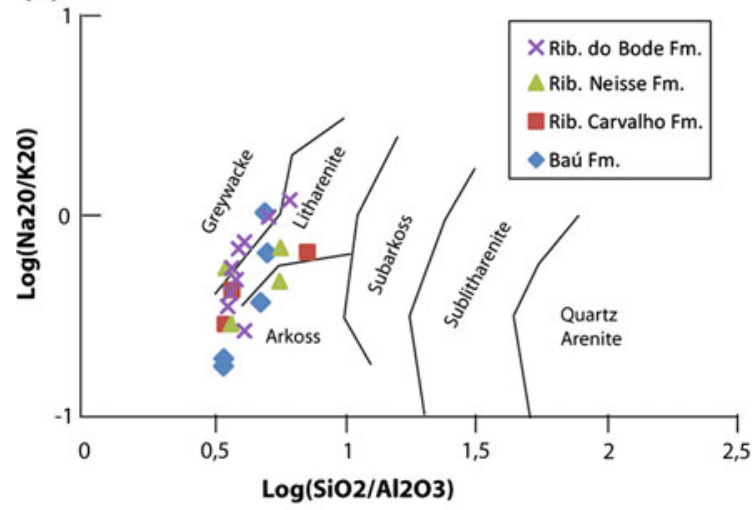

(b)

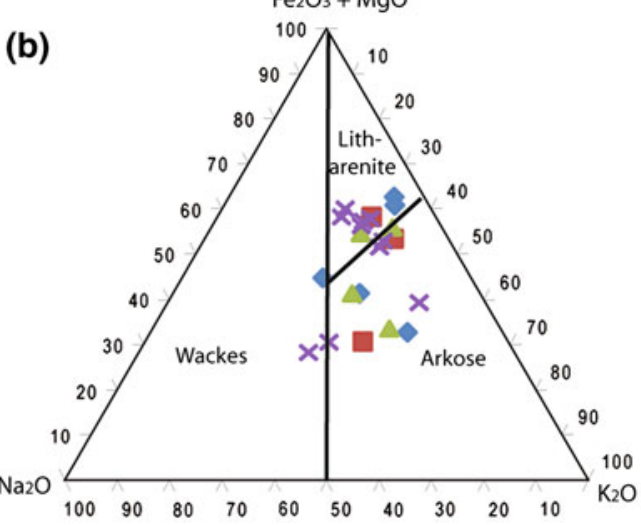

(c)

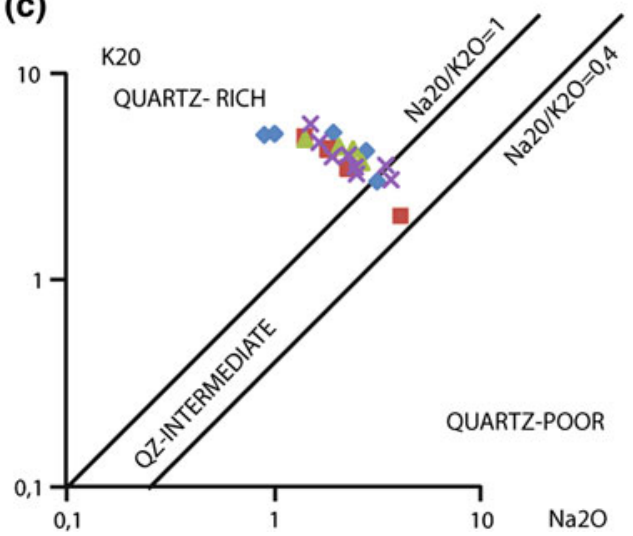

Fig. 12 Classification of sedimentary rocks according to major element contents. a Geochemical classification of terrigenous sandstones (Pettijohn et al. 1972); b Chemical classification of sandstones (d)
Formation sediments (lower sequence) were rocks associated with an old crust, whereas the source area for the Ribeirão Carvalhos, Ribeirão Neisse, and Ribeirão do Bode Formations (upper sequence) were rocks associated with more juvenile, upper crustal rocks.

The geochemical studies of the Itajaí Basin sedimentary rocks helped characterize the rock types analyzed as mineralogically immature, represented by wackes, arkoses, and shale. The interpretation of REE data shows that different samples coming from the same units yielded very homogeneous results, whereas significant differences occur between samples from the continental unit and from the marine units, which attests for the reliability of the proposed lithostratigraphic column.

As indicated by the present study, the continental collision, passive margin, and magmatic arc settings can be suggested as probable settings related to the source areas for the Itajaí Basin sediments. It was equally possible to characterize the predominance of sediments coming from an old crust to the basal unit (Baú Formation) and from a younger upper crust to the upper units.

\section{Isotopic Geochemistry}

The $\mathrm{Nd}, \mathrm{Sr}$, and $\mathrm{Pb}$ isotopic study was carried out using the same 23 Itajaí Basin stratigraphic sequence samples as for the lithogeochemical studies. For the ${ }^{143} \mathrm{Nd} /{ }^{144} \mathrm{Nd}$ and ${ }^{207} \mathrm{~Pb} /{ }^{204} \mathrm{~Pb}$ data (Fig. 15), more radiogenic values correspond to the Carvalho, Ribeirão Neisse, and Ribeirão do Bode Formations, whereas less radiogenic values correspond at least to the basal portions of the Baú Formation. This fact strengthens the lithostratigraphic organization proposed and supports the suggestion that the sandstone and conglomerate units of the Itajaí Basin southern border constitute, as indicated in the geologic map, the same Baú Formation described in the northern border, therefore ruling out a third unit as suggested by Appi (1990), Appi and Cruz (1991), Rostirolla et al. (1992, 1999); Fonseca (2004) and Guadagnin (2007).

Still aiming at identifying the possible source areas for the Itajaí Basin sediments, $\varepsilon_{\mathrm{Nd}}$ values for samples of the Itajaí Basin and the adjacent terranes were calculated for $580 \mathrm{Ma}$, which is the mean age estimated for the Itajaí 
(a)

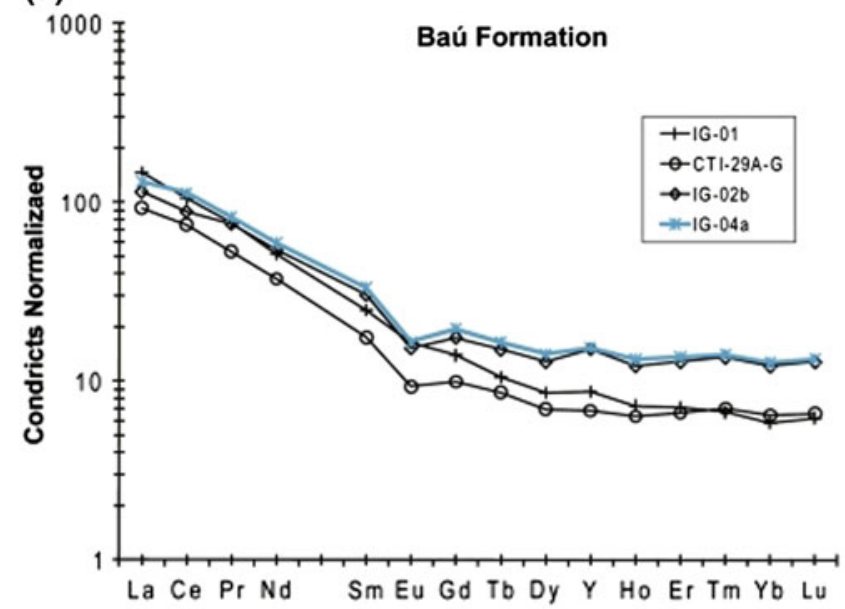

(c)

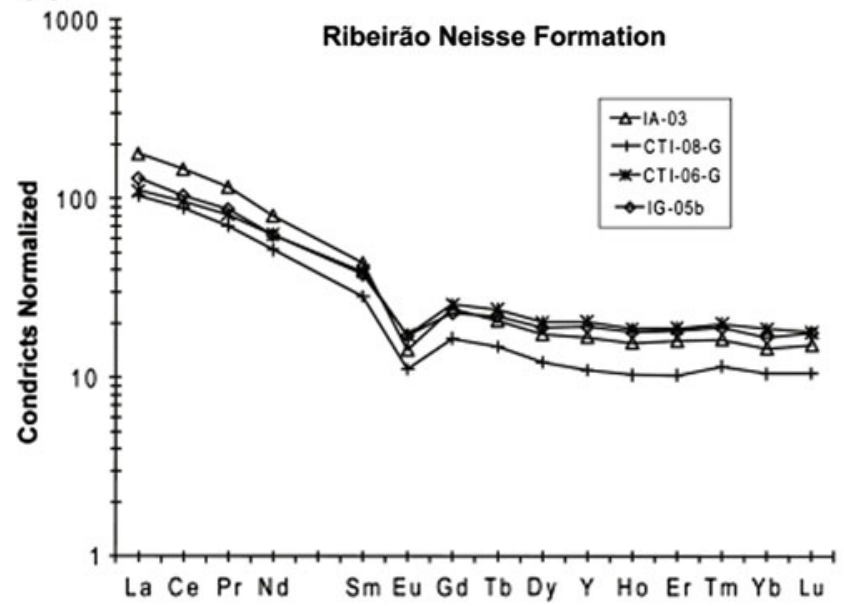

(b)

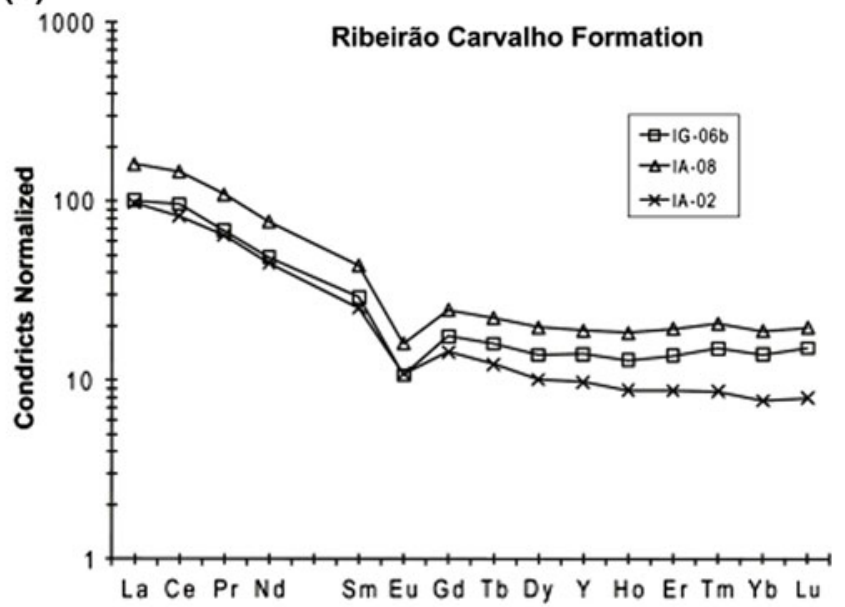

(d)

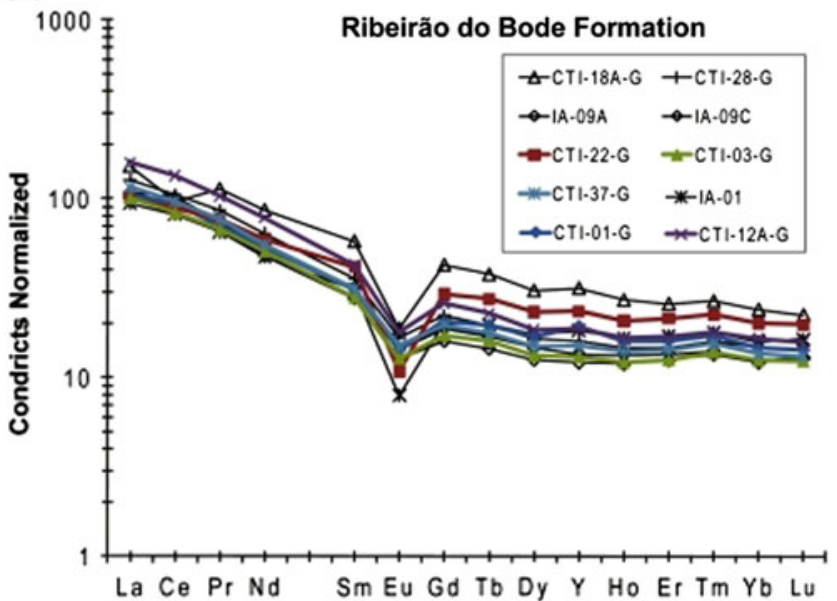

Fig. 13 Chondrite-normalized REE distribution (McLennan et al. 1995). a Baú, b Ribeirão Carvalho, c Ribeirão Neisse and d Ribeirão do Bode Formations, evidencing similar characteristics of samples from the same unit and differences between the Baú Formation and the upper units

sedimentation (Basei et al. 2008b). As seen in Fig. 16a, the calculated $\varepsilon_{\mathrm{Nd}}$ values for the distinct crustal segments that host the Itajaí Basin are organized according their geographic distribution along a NW-SE section. This figure shows the predominance of more negative $\varepsilon_{\mathrm{Nd}}$ values in the Baú Formation. These values are similar to those obtained for the Santa Catarina Granulitic Complex gneisses and indicate that the source area for the Itajaí Basin basal unit are old rocks with long crustal residence, which is in agreement with the other geochemical-isotopic information that points to these gneisses as source for these sediments. On the other hand, the values obtained for the Itajaí Basin upper units are similar to those for the Brusque Group metasediments and granites, and even to those for the Florianópolis Batholith. Comparing the $\varepsilon_{\mathrm{Nd}}(580)$ and $\varepsilon_{\mathrm{Sr}}$ (580) calculated for the Itajaí Basin sediments values, two distinct evolution trends are depicted (dashed arrows in Fig. 16b). The upper units yield approximately constant and slightly negative $\varepsilon_{\mathrm{Nd}}$ values and $\varepsilon_{\mathrm{Sr}}$ values falling in a large interval. These data plot close to the points corresponding to the Brusque Group and Florianópolis Batholith. On the other hand, it is possible to suggest a second trend defined by the Baú Formation points that indicates more negative values, closer to the points corresponding to the Luís Alves Microplate basement gneisses. Thus, it is again suggested that the possible source areas for the Baú Formation are the Santa Catarina Granulitic Complex, the Camboriú Complex, and the Brusque Group granites.

The same provenance relationships can be inferred from Fig. 16c, where the fields of $\mathrm{Nd}$ evolution through time (DePaolo 1988) are presented. The field defined by the Itajaí Basin completely overlaps the field defined by the Brusque Group metasediments and partially overlaps with the fields that represent the Santa Catarina Granulitic Complex, the Florianópolis Batholith, and the Brusque Group granites. The field corresponding to the Camboriú Complex model ages is very ample and almost totally overlaps the other fields. 


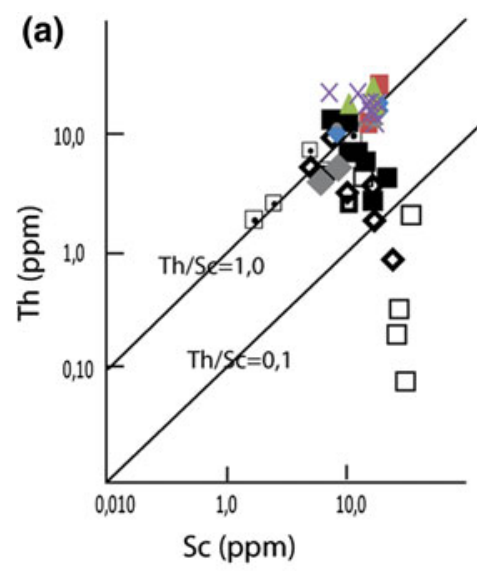

(c)

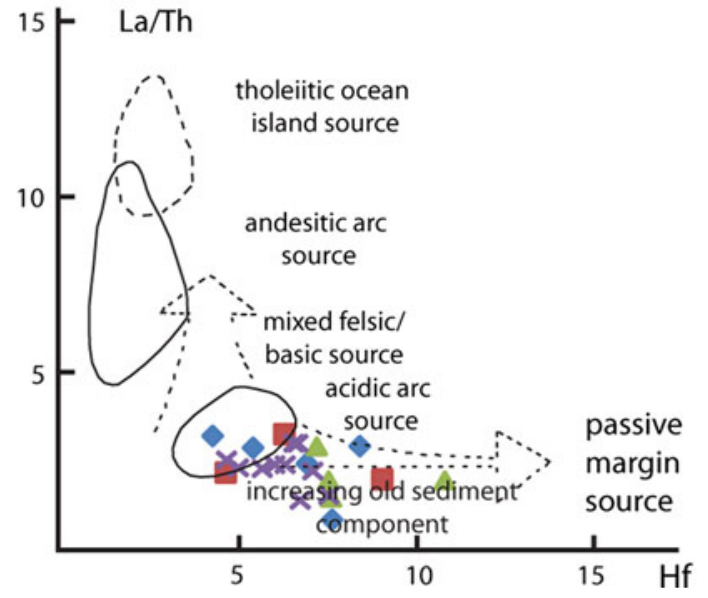

Fig. 14 Geochemical characterization of the provenance areas for the Itajaí Group sediments. a Th/Sc diagram (McLennan et al. 1990); b $\mathrm{SiO}_{2}+\mathrm{Al}_{2} \mathrm{O}_{3}$ vs. $\mathrm{K}_{2} \mathrm{O}+\mathrm{Na}_{2} \mathrm{O}$ diagram (McLennan et al. 1990);

Fig. $15{ }^{207} \mathrm{~Pb} /{ }^{204} \mathrm{~Pb}$ and ${ }^{143} \mathrm{Nd} /{ }^{144} \mathrm{Nd}$ ratios versus stratigraphic column, characterizing similar isotopic behavior between the upper marine units and differences between these units and the lower continental unit (Baú Formation)

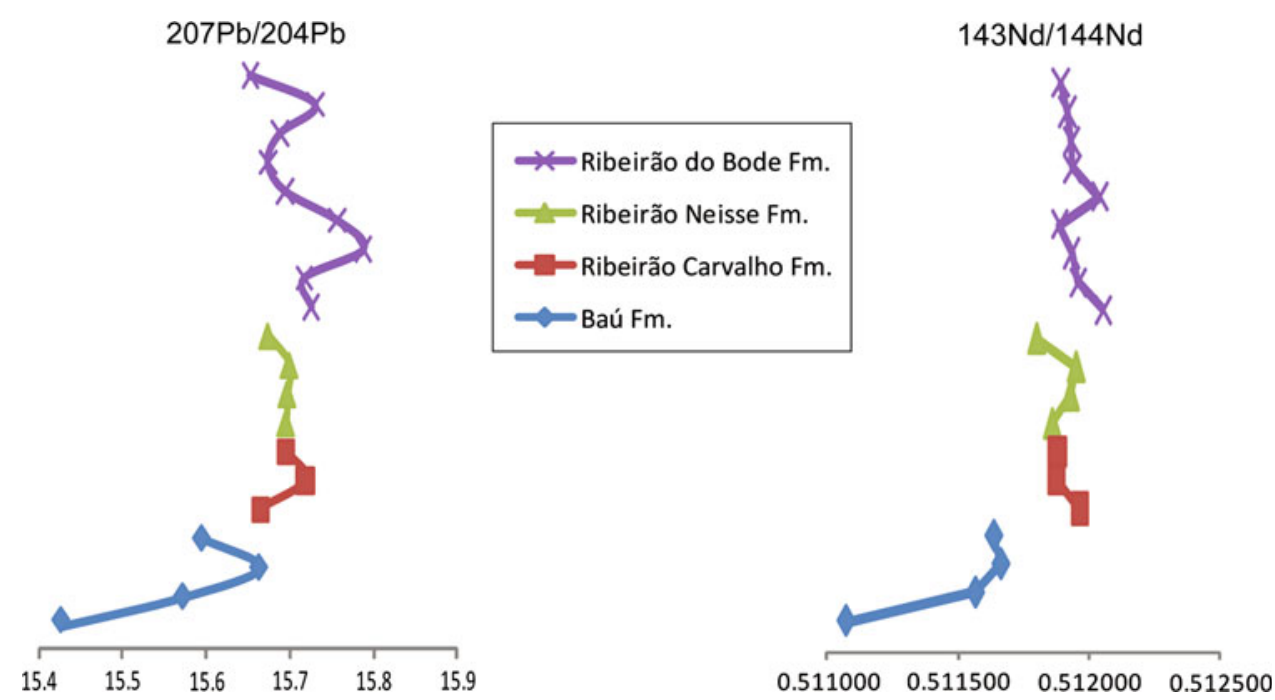

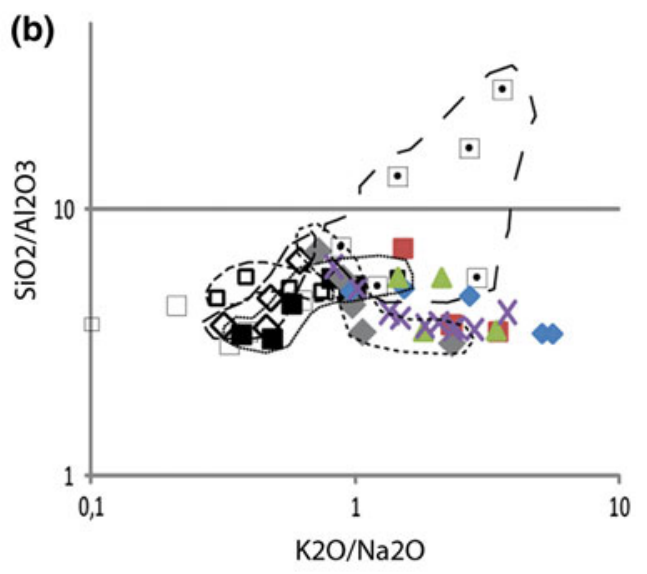

(d)

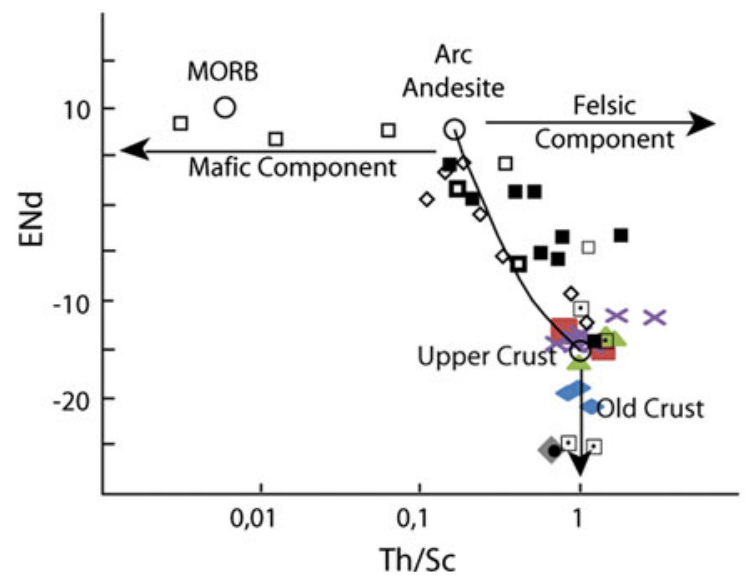

c La/Th vs. Hf diagram (Floyd and Leveridge 1987); d $\varepsilon_{\mathrm{Nd}}$ vs. Th/Sc diagram (McLennan et al. 1990)
In conclusion, the isotopic study indicates that the rhythmites and siltites of the Itajaí basin upper sequence (Ribeirão Carvalho, Ribeirão Neisse and Bode Formations) are isotopically homogeneous and but significantly different from the lower sequence (Baú Formation) constituted by the continental sandstones and conglomerates. For the 
Fig. 16 Isotopic diagrams comparing $\varepsilon_{\mathrm{Nd}}$ values for the Itajaí Basin and the main regional geologic units (Santa Catarina Granulitic Complex, Camboriú Complex,

Florianópolis Batholith, Brusque Group metasediments and intrusive granites), a values of $\varepsilon_{\mathrm{Nd}(580)}$ for all regional units organized geographically according to a NW-SE section; b $\varepsilon_{\mathrm{Nd}(580)}$ vs. $\varepsilon \mathrm{S}_{\mathrm{r}(580)}$ indicating distinct evolutionary trends for upper and lower Itajaí Group units (a)

ENd (580)

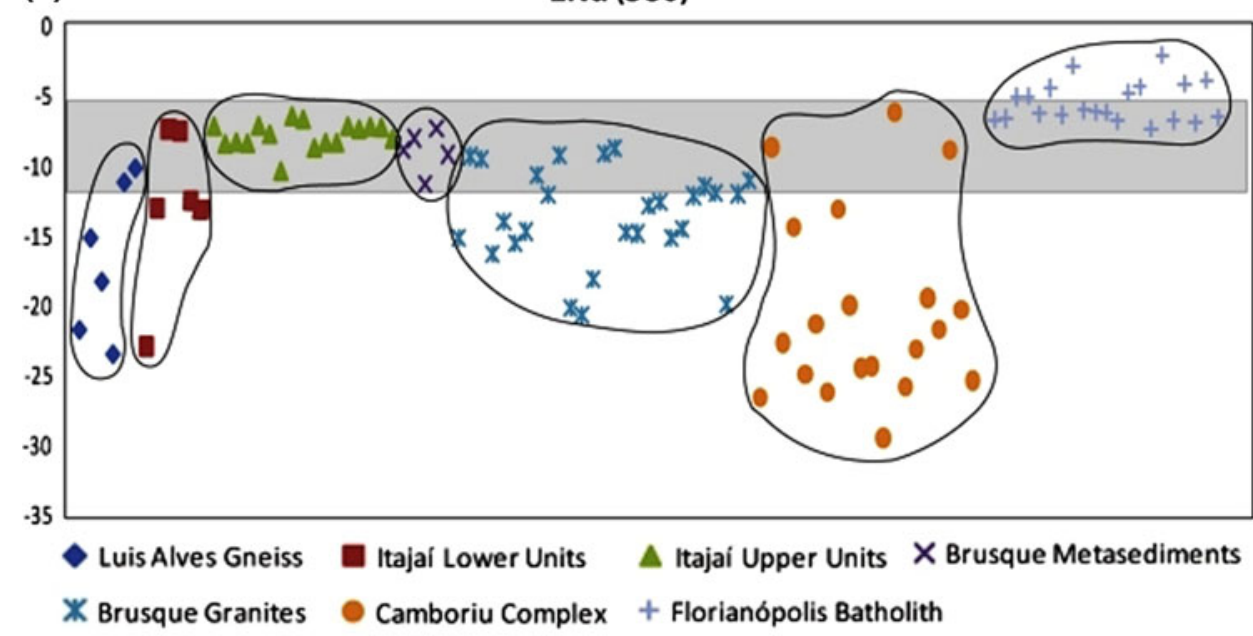

(b)

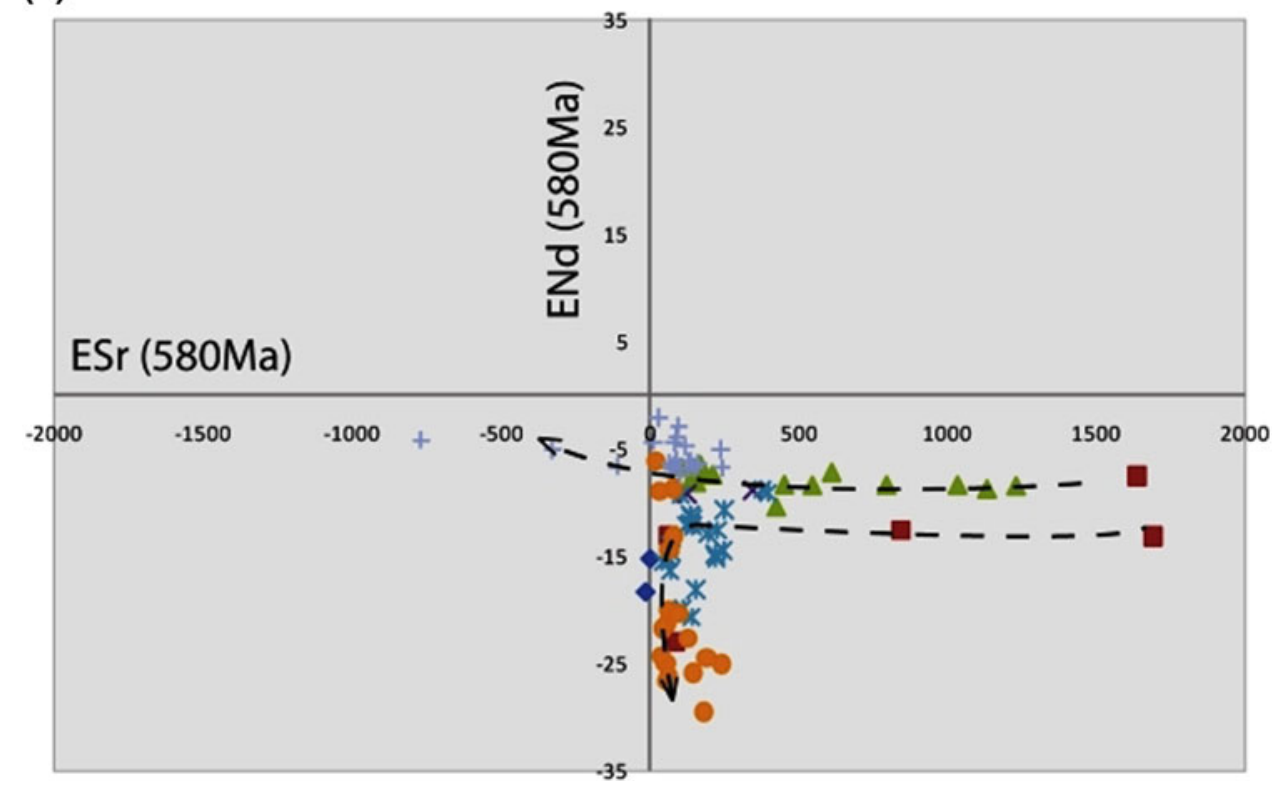

upper sequence, the ${ }^{143} \mathrm{Nd} /{ }^{144} \mathrm{Nd}$ and ${ }^{207} \mathrm{~Pb} /{ }^{204} \mathrm{~Pb}$ ratios are always more radiogenic and the $\varepsilon_{\mathrm{Nd}}$ values less negative than those yielded by the lower sequence. Model ages ( Nd TDM) indicate for all the Basin units a long crustal residence, with values similar to those observed in the Brusque Group, the Florianópolis Batholith and the Camboriú Complex, and subordinately similar to those of the Santa Catarina Granulitic Complex.

The isotopic data suggest the continental sandstones and conglomerates of the Baú Formation originated by the erosion of the basement, notably the Santa Catarina Granulitic Complex, and for the source area for the rhythmites, sandstones, and siltites of the upper marine pile it was the Brusque Group metavolcano-sedimentary sequence, with contributions from the Florianópolis Batholith. This provenance is confirmed by field data. In the Baú Formation, centimeter- to meter-sized gneiss, granite, vein quartz, quartzite, and mylonite clasts, related to the Santa Catarina Granulitic Complex, and rare mica-schist fragments related to the Brusque Group are observed. In the upper units, the provenance associated with the Brusque Group is observed in thin sections, where the predominance of mica schists fragments is observed.

\section{Geochronology}

The first Itajaí Group geochronological results were presented by Macedo et al. (1984) who, on the basis of $\mathrm{Rb}-\mathrm{Sr}$ isochrons of whole rock fine fractions, placed the sedimentation and diagenesis around $560 \mathrm{Ma}$. Based on $\mathrm{Rb}-\mathrm{Sr}$ ages and U-Pb (TIMS) zircon analysis, Basei 1985 and Basei et al. (1999) also confined the depositional history of the Itajaí Basin to the Neoproterozoic. In disagreement 
Table 2 K-Ar data of muscovite crystal

\begin{tabular}{lllllllll}
\hline Field number & Geological unit & Rock type & Mineral & $\mathrm{K}_{2} \mathrm{O}(\mathrm{wt} \%)$ & $40 \mathrm{Ar} *[\mathrm{nl} / \mathrm{g}] \mathrm{STP}$ & 40 Ar* $(\%)$ & Age (Ma) & $2 \mathrm{~s}$ Error (Ma) \\
\hline BR 24 & Bau Fm. & Conglomerate & Muscovite & 10.62 & 1015.53 & 99.47 & 1754.40 & 37.40 \\
BR 25 & Bau Fm. & Conglomerate & Muscovite & 10.69 & 983.10 & 99.57 & 1711.00 & 39.00 \\
\hline
\end{tabular}

with what was mentioned above, the identification of fossil traces and evidence of Chancelloria led Pain et al. (1997) to place the Itajaí sedimentation in the Cambrian, with the oldest possible age at $540 \mathrm{Ma}$. The deformation that affected the Itajaí Basin transformed to quartz-sericite schists by shearing the tuffaceous sediments intercalated with the basal arkosic sandstones yielded a $535 \pm 11 \mathrm{Ma}$ (Basei 1985). K-Ar fine fractions analysis $(<2 \mu \mathrm{m})$ of two siltstone quarries located near Blumenau and Apiúna show $517 \pm 5.0 \mathrm{Ma}$ and $535 \pm 11 \mathrm{Ma}$, respectively Macedo et al. (1984). These two different groups of ages suggest diachronism among the low-temperature events that characterize the thermal evolution of the Itajaí Basin.

A large detrital muscovite crystal of the Baú Formation conglomerates (BR 470 highway, in the proximity of Pedra de Amolar) were dated at Georg-August University, Gottingen, Germany, yielding ages of $1,754 \pm 37 \mathrm{Ma}$ and $1,711 \pm 39 \mathrm{Ma}$ (Table 2). These ages reinforce the suggestion given by the isotopic geochemistry, which points to the Paleoproterozoic Luís Alves Microplate gneissic basement as source for the basal continental successions. Similar conclusion was obtained by Guadagnin et al. (2010) who, on the basis of $\mathrm{Nd}$ and $\mathrm{Pb}$ isotopes, also indicated the importance of the Brusque Group as the main supplier of material for the Itajaí Basin (Guadanin et al. 2010). It is interesting to stress that this author showed (main) concentrations of ages around $600 \mathrm{Ma}$ and a second group of $c a .800 \mathrm{Ma}$ for the detrital zircons from the sandy sediments. The first group can be easily attributed to the Brusque Group granitoids, whereas the provenance for the second is still uncertain, once rocks of such age are rare, restricted to the Parapente Suite A-type magmatism (Basei et al. 2008c) of very local expression in the region.

For the zircon, SHRIMP ages presented in this paper, mineral separation was by standard gravimetric and isodynamic techniques, and the mounting of selected zircons into epoxy resin discs were carried out at the Instituto de Geociências, Universidade de São Paulo. Prior to analysis, cathodo-luminescence (CL) images were obtained to pick sites for analysis. Age determinations were performed at the Beijing Shrimp Center, China and Research School of Earth Sciences, Australia, according to standard procedures (Compston et al. 1984; Williams 1998; Stern 1998; Sircombe 2000). Data are portrayed in Tera Wasserburg diagrams generated by the program Isoplot/Ex (Ludwig 2001; Table 3). The SHRIMP method was applied to zircons from sample MBAN 1 of the same tuffaceous levels investigated by the $\mathrm{Rb}-\mathrm{Sr}$ method (Fig. 18a). A weighted mean ${ }^{206} \mathrm{~Pb} /{ }^{238} \mathrm{U}$ age of $596 \pm 10 \mathrm{Ma}$ (Fig. 17a) was obtained for the volcanogenic components and is the best estimate for the beginning of the deposition of the Itajaí Group basal portion. In two distinct localities, conglomerate levels rich in felsic volcanic clasts (Fig. 18b, c) caused much controversy regarding the stratigraphic position of this felsic magmatism. Geochronologic studies using zircons extracted from centimeter-sized fragments of felsic rock clasts (from both outcrops resulted in ${ }^{206} \mathrm{~Pb} /{ }^{238} \mathrm{U}$ ages around $609 \mathrm{Ma}$ (Fig. 17b, c). Considering the age errors, these results are coeval with the MBAN 1 tuffaceous sample of Bau Formation and with those observed in the Campo Alegre Basin. It represents a volcanic event, whose products were already recycled by erosion, which occurred prior to the felsic magmatism that can be recognized in the Itajaí Basin and represented by lava domes. No relationship exists between the felsic rich clast conglomerates and the late, felsic volcanism.

The best age for the Itajaí Basin felsic volcanism (Apiúna Formation) was obtained for the dome that occurs south of Apiúna (Morro do Gravatá), composed of felsic rocks (Fig. 18d) that crosscut the basin units. The ${ }^{206} \mathrm{~Pb} /{ }^{238} \mathrm{U}$ age of $558 \pm 6.6 \mathrm{Ma}$ (Fig. 17d) represents the youngest age possible for the Itajaí Group sedimentation.

The Subida syenogranite (Fig. 18e), intrusive in the Itajaí Basin sediments, represents the youngest anorogenic granitoid recognized in the region. Its ${ }^{206} \mathrm{~Pb} /{ }^{238} \mathrm{U}$ age of $520 \pm 5.5 \mathrm{Ma}$ (Fig. 17e) is circa 80-60 Ma younger than the A-type granitoids of the Serra do Mar Suite (Kaul 1984, Vlach and Gualda 2007), with which it has always been correlated.

\section{Comparative analysis}

Considering the importance of the recently published paper by Guadagnin et al. (2010) to our manuscript, a brief comparison of both works is carried out here. In a general way, both works make use of stratigraphic, isotopic, and geochronologic information on the Itajaí Basin units and present a proposal for the Itajaí Basin tectonic evolution, on the basis of their own data. Despite the tools used (LA ICPMS and SHRIMP) led to comparable results, they were applied to distinct materials: detrital zircons (Guadagnin 
Table 3 U-Pb SHRIMP analytical data

\begin{tabular}{|c|c|c|c|c|c|c|c|c|c|}
\hline Labels & Site & $\mathrm{U}(\mathrm{ppm})$ & Th (ppm) & $\mathrm{Th} / \mathrm{U}$ & $\pm \mathrm{Th} / \mathrm{U}$ & $\mathrm{Pb}^{*}(\mathrm{ppm})$ & $204(\mathrm{ppb})$ & $238 \mathrm{U} / 206 \mathrm{~Pb}$ & $\pm 38 / 6$ \\
\hline \multicolumn{10}{|c|}{ MBAN-1—Siltstone with tuffaceous contribution—Baú Formation (corrected using measured 204Pb) } \\
\hline 1.1 & e,osc,p & 285.51 & 263.56 & 0.92314 & 0.02286 & 34 & 2 & 9.83396 & 0.45643 \\
\hline 2.1 & e,osc,p & 427.97 & 168.33 & 0.39332 & 0.00587 & 41 & 4 & 10.67875 & 0.52071 \\
\hline 3.1 & $\mathrm{e}, \mathrm{osc} / \mathrm{hd}, \mathrm{p}$ & 1203.27 & 596.74 & 0.49593 & 0.01932 & 113 & 36 & 11.03623 & 0.8314 \\
\hline 4.1 & $\mathrm{e}, \mathrm{osc}, \mathrm{p}$ & 647.1 & 779.85 & 1.20515 & 0.01952 & 79 & 4 & 10.15616 & 0.43155 \\
\hline 6.1 & $\mathrm{~m}, \mathrm{osc}, \mathrm{p}$ & 304 & 288.41 & 0.94873 & 0.03036 & 33 & 3 & 10.64369 & 0.69462 \\
\hline 5.1 & e,osc,p & 335.43 & 188.88 & 0.56309 & 0.01309 & 37 & 0 & 9.64532 & 0.59014 \\
\hline 9.1 & $\mathrm{e}, \mathrm{h}, \mathrm{p}$ & 417.45 & 245.59 & 0.58831 & 0.01795 & 41 & 9 & 10.66171 & 0.70708 \\
\hline 7.1 & m,hd,p & 1453.97 & 805.87 & 0.55426 & 0.07225 & 142 & 318 & 10.99862 & 1.87312 \\
\hline 8.1 & $\mathrm{~m}, \mathrm{dd}, \mathrm{p}$ & 2404.28 & 1700.25 & 0.70718 & 0.03159 & 115 & 945 & 23.08662 & 2.33238 \\
\hline 10.1 & $\mathrm{e}, \mathrm{osc}, \mathrm{p}$ & 452.49 & 350.83 & 0.77534 & 0.01601 & 161 & 5 & 3.23886 & 0.17454 \\
\hline \multicolumn{10}{|c|}{ CT31 and CT 32—clasts of felsic volcanic-Itajaí conglomerates (corrected using measured 204Pb) } \\
\hline $31-1.1$ & m,osc,p & 124.58 & 40.74 & 0.32702 & 0.00351 & 16 & 6 & 7.4654 & 0.18198 \\
\hline $31-2.1$ & $\mathrm{~m}, \mathrm{osc}, \mathrm{p}, \mathrm{fr}$ & 61.81 & 40.19 & 0.65021 & 0.0095 & 6 & 0 & 10.62627 & 0.36401 \\
\hline $31-3.1$ & e,osc,p,fr & 46.95 & 37.11 & 0.79047 & 0.01219 & 5 & 2 & 10.1916 & 0.31442 \\
\hline $31-4.1$ & $\mathrm{~m}, \mathrm{osc}, \mathrm{fr}$ & 127.87 & 97.83 & 0.76507 & 0.00808 & 14 & 0 & 10.12963 & 0.30119 \\
\hline $31-5.1$ & $\mathrm{e}, \mathrm{osc}, \mathrm{p}, \mathrm{fr}$ & 200.21 & 146.29 & 0.73068 & 0.00689 & 23 & 6 & 9.48737 & 0.23723 \\
\hline $31-6.1$ & $\mathrm{e}, \mathrm{osc} / \mathrm{h}, \mathrm{p}$ & 158.01 & 203.54 & 1.28816 & 0.02637 & 19 & 5 & 10.38479 & 0.4046 \\
\hline $31-7.1$ & $\mathrm{e}, \mathrm{osc}, \mathrm{p}$ & 139.27 & 192.63 & 1.38316 & 0.01961 & 17 & 5 & 10.30378 & 0.26595 \\
\hline $31-8.1$ & $\mathrm{~m}, \mathrm{osc}, \mathrm{p}, \mathrm{fr}$ & 181.77 & 54.4 & 0.29927 & 0.00537 & 18 & 2 & 9.72529 & 0.34106 \\
\hline $31-9.1$ & $\mathrm{e}, \mathrm{osc}, \mathrm{p}, \mathrm{fr}$ & 116.64 & 135.94 & 1.16549 & 0.01266 & 14 & 2 & 10.13557 & 0.26576 \\
\hline $31-10.1$ & e,osc,p & 652.68 & 118.86 & 0.18211 & 0.0051 & 66 & 17 & 9.55815 & 0.75126 \\
\hline $32-1.1$ & $\mathrm{~m}, \mathrm{osc}, \mathrm{p}$ & 90.66 & 158.56 & 1.74904 & 0.02591 & 12 & 1 & 10.40936 & 0.3242 \\
\hline $32-2.1$ & $\mathrm{e}, \mathrm{osc}, \mathrm{p}, \mathrm{fr}$ & 154.2 & 238.14 & 1.54432 & 0.01988 & 22 & 1 & 9.49905 & 0.32357 \\
\hline $32-3.1$ & $\mathrm{e}, \mathrm{osc}, \mathrm{p}$ & 525.74 & 380.38 & 0.72351 & 0.01496 & 55 & 2 & 10.60783 & 0.414 \\
\hline $32-4.1$ & $\mathrm{e}, \mathrm{osc}, \mathrm{p}$ & 34.71 & 95.64 & 2.75507 & 0.06982 & 6 & 1 & 10.25406 & 0.39509 \\
\hline $32-5.1$ & $\mathrm{e}, \mathrm{osc}, \mathrm{p}$ & 321.15 & 211.03 & 0.65711 & 0.00774 & 37 & 3 & 9.44281 & 0.25074 \\
\hline $32-6.1$ & $\mathrm{e}, \mathrm{osc}, \mathrm{p}$ & 328.45 & 774.78 & 2.3589 & 0.03898 & 51 & 1 & 9.91756 & 0.18395 \\
\hline $32-7.1$ & $\mathrm{e}, \mathrm{osc}, \mathrm{p}$ & 184.03 & 263.48 & 1.43169 & 0.05636 & 23 & 4 & 10.11287 & 0.47959 \\
\hline $32-8.1$ & $\mathrm{~m}, \mathrm{osc} / \mathrm{h}, \mathrm{p}$ & 122.32 & 128.01 & 1.04657 & 0.01497 & 13 & 6 & 10.60417 & 0.32207 \\
\hline $32-9.1$ & e,osc,p,fr & 83.21 & 82.44 & 0.99071 & 0.00934 & 9 & 0 & 10.51133 & 0.2621 \\
\hline $32-10.1$ & e,osc,p,fr & 119.99 & 62.26 & 0.51888 & 0.00564 & 13 & 2 & 10.0703 & 0.18618 \\
\hline $32-12.1$ & $\mathrm{e}, \mathrm{osc}, \mathrm{p}, \mathrm{fr}$ & 140.63 & 141.95 & 1.00942 & 0.02793 & 16 & 4 & 10.57562 & 0.60027 \\
\hline $32-15.1$ & $\mathrm{~m}, \mathrm{osc}, \mathrm{p}$ & 426.95 & 187.19 & 0.43844 & 0.00398 & 44 & 13 & 9.87361 & 0.24513 \\
\hline $32-17.1$ & $\mathrm{e}, \mathrm{osc}, \mathrm{p}, \mathrm{fr}$ & 52.75 & 78.5 & 1.48807 & 0.05665 & 7 & 2 & 10.30806 & 0.53613 \\
\hline $32-18.1$ & $\mathrm{~m}, \mathrm{osc}, \mathrm{p}$ & 196.43 & 139.34 & 0.70933 & 0.00856 & 21 & 1 & 10.18354 & 0.29523 \\
\hline $32-13.1$ & $\mathrm{e}, \mathrm{osc}, \mathrm{p}$ & 159.89 & 178.36 & 1.11549 & 0.01255 & 82 & 6 & 2.43406 & 0.06579 \\
\hline $32-14.1$ & $\mathrm{e}, \mathrm{osc}, \mathrm{p}$ & 146.21 & 41.77 & 0.2857 & 0.00524 & 30 & 5 & 4.94949 & 0.23435 \\
\hline $32-11.1$ & $\mathrm{~m}, \mathrm{osc}, \mathrm{p}$ & 194.58 & 64.51 & 0.33156 & 0.00359 & 25 & 2 & 7.79364 & 0.21668 \\
\hline $32-16.1$ & e,osc,p & 316.45 & 160.23 & 0.50634 & 0.00341 & 45 & 1 & 7.42249 & 0.1326 \\
\hline \multicolumn{10}{|c|}{ Felsic volcanic-Apiúna Formation (corrected using measured 204Pb) } \\
\hline API-1.1 & $\mathrm{e}, \mathrm{h}, \mathrm{p}$ & 40.83 & 29.13 & 0.71356 & 0.00871 & 4 & 0 & 11.03503 & 0.34407 \\
\hline API-2.1 & $\mathrm{e}, \mathrm{h}, \mathrm{p}$ & 47.7 & 49.1 & 1.02937 & 0.01716 & 5 & 0 & 10.90571 & 0.34625 \\
\hline API-4.1 & $\mathrm{e}, \mathrm{h}, \mathrm{p}$ & 83.14 & 92.11 & 1.10787 & 0.0134 & 9 & 0 & 11.00483 & 0.25872 \\
\hline API-5.1 & $\mathrm{e}, \mathrm{h}, \mathrm{p}$ & 54.64 & 34.69 & 0.63482 & 0.00933 & 5 & 0 & 11.03706 & 0.28964 \\
\hline API-6.1 & $\mathrm{e}, \mathrm{h}, \mathrm{p}$ & 59.91 & 63.18 & 1.05445 & 0.01317 & 6 & 1 & 11.33351 & 0.32143 \\
\hline API-3.1 & $\mathrm{e}, \mathrm{h}, \mathrm{p}$ & 34.65 & 34.36 & 0.9918 & 0.01666 & 4 & 2 & 11.2193 & 0.37863 \\
\hline
\end{tabular}


Table 3 continued

\begin{tabular}{|c|c|c|c|c|c|c|c|c|c|}
\hline Labels & Site & $\mathrm{U}(\mathrm{ppm})$ & Th (ppm) & $\mathrm{Th} / \mathrm{U}$ & $\pm \mathrm{Th} / \mathrm{U}$ & $\mathrm{Pb}^{*}(\mathrm{ppm})$ & $204(\mathrm{ppb})$ & $238 \mathrm{U} / 206 \mathrm{~Pb}$ & $\pm 38 / 6$ \\
\hline \multicolumn{10}{|c|}{ Subida Granite (corrected using measured 204Pb) } \\
\hline A SUB-1.1 & e,osc,p & 205.44 & 125.59 & 0.6113 & 0.01425 & 19 & 5 & 11.51098 & 0.6656 \\
\hline A SUB-2.1 & $\mathrm{e}, \mathrm{osc}, \mathrm{p}, \mathrm{fr}$ & 103.58 & 77.9 & 0.75212 & 0.02191 & 10 & 1 & 11.45334 & 0.67073 \\
\hline A SUB-3.1 & $\mathrm{e}, \mathrm{osc}, \mathrm{p}$ & 320.97 & 160.77 & 0.5009 & 0.01819 & 28 & 2 & 11.94992 & 0.96808 \\
\hline A SUB-4.1 & e,osc,p & 124.39 & 92.72 & 0.74543 & 0.01704 & 12 & 2 & 11.50705 & 0.64287 \\
\hline A SUB-5.1 & $\mathrm{e}, \mathrm{osc}, \mathrm{p}$ & 129.49 & 101.48 & 0.78368 & 0.01671 & 12 & 3 & 11.83973 & 0.78047 \\
\hline A SUB-6.1 & $\mathrm{e}, \mathrm{osc}, \mathrm{p}$ & 134.03 & 78 & 0.58197 & 0.01012 & 12 & 2 & 11.49571 & 0.52939 \\
\hline C SUB-7.1 & e,osc,p & 98.74 & 60.86 & 0.61638 & 0.01003 & 9 & 1 & 11.78418 & 0.60083 \\
\hline C SUB-8.1 & e,osc,p & 148.16 & 79.29 & 0.53518 & 0.00857 & 13 & 4 & 12.17256 & 0.66257 \\
\hline C SUB-9.1 & $\mathrm{e}, \mathrm{h}, \mathrm{p}$ & 143.7 & 99.08 & 0.68949 & 0.01244 & 13 & 2 & 12.15569 & 0.68554 \\
\hline C SUB-10.1 & e,osc/hd,p & 311.73 & 304.27 & 0.97607 & 0.00899 & 31 & 4 & 11.70655 & 0.50583 \\
\hline C SUB-11.1 & e,hd,p & 236.96 & 250.61 & 1.05758 & 0.0131 & 24 & 1 & 11.86382 & 0.6185 \\
\hline C SUB-12.1 & e,hd,eq & 553.05 & 1159.97 & 2.09741 & 0.02685 & 70 & 1 & 11.57709 & 0.56569 \\
\hline NC SUB-2.1 & $\mathrm{e}, \mathrm{osc}, \mathrm{p}$ & 182.44 & 151.48 & 0.83027 & 0.01486 & 17 & 18 & 11.95746 & 0.40462 \\
\hline NC SUB-3.1 & $\mathrm{m}, \mathrm{osc}, \mathrm{p}$ & 143.35 & 137.69 & 0.96055 & 0.01252 & 14 & 11 & 11.8394 & 0.38049 \\
\hline NC SUB-7.1 & $\mathrm{m}, \mathrm{h}, \mathrm{osc}$ & 146.48 & 126.41 & 0.86301 & 0.01224 & 14 & 17 & 11.99367 & 0.37179 \\
\hline NC SUB-1.1 & $\mathrm{e}, \mathrm{osc}, \mathrm{p}$ & 254.19 & 162.25 & 0.6383 & 0.00898 & 26 & 12 & 10.27715 & 0.28975 \\
\hline NC SUB-4.1 & e,p,og & 43.55 & 37.11 & 0.85209 & 0.01207 & 4 & 21 & 12.01428 & 0.54006 \\
\hline NC SUB-5.1 & $\mathrm{m}, \mathrm{p}, \mathrm{osc}, \mathrm{h}, \mathrm{fr}$ & 17.38 & 40.22 & 2.31356 & 0.05317 & 2 & 10 & 12.89028 & 0.69512 \\
\hline NC SUB-6.1 & $\mathrm{m}, \mathrm{osc}, \mathrm{p}, \mathrm{fr}$ & 71.54 & 103.04 & 1.44038 & 0.02302 & 8 & 19 & 11.79446 & 0.43072 \\
\hline NC SUB-8.1 & $\mathrm{m}, \mathrm{osc}, \mathrm{p}$ & 111.72 & 110.32 & 0.98743 & 0.01806 & 10 & 12 & 12.9293 & 0.44761 \\
\hline Labels & $207 \mathrm{~Pb} / 206 \mathrm{~Pb}$ & $\pm 7 / 6$ & Age $206 / 238$ & \pm Age & Age $(207 / 235)$ & \pm age & Age $(207 / 206)$ & \pm age & Conc $(\%)$ \\
\hline MBAN-1-Silt & ltstone with tufface & eous contributi & ion-Baú Form & on (correcte & using measured & d 204Pb) & & & \\
\hline 1.1 & 0.05938 & 0.00185 & 624.3 & 27.7 & 615.0 & 27.6 & 580.9 & 69.3 & 107.5 \\
\hline 2.1 & 0.0578 & 0.00123 & 577.1 & 27.0 & 566.1 & 24.4 & 522.1 & 47.3 & 110.5 \\
\hline 3.1 & 0.05935 & 0.00144 & 559.2 & 40.5 & 563.3 & 36.1 & 580.1 & 53.7 & 96.4 \\
\hline 4.1 & 0.06024 & 0.00127 & 605.4 & 24.6 & 606.8 & 23.0 & 612.3 & 46.2 & 98.9 \\
\hline 6.1 & 0.05892 & 0.00188 & 578.9 & 36.2 & 575.9 & 34.0 & 564.0 & 70.9 & 102.6 \\
\hline 5.1 & 0.06239 & 0.00118 & 635.9 & 37.2 & 647.4 & 32.2 & 687.6 & 40.8 & 92.5 \\
\hline 9.1 & 0.05539 & 0.0019 & 577.9 & 36.8 & 548.5 & 33.8 & 428.1 & 78.5 & 135.0 \\
\hline 7.1 & 0.06904 & 0.01105 & 561.0 & 92.2 & 633.1 & 124.1 & 899.8 & 370.8 & 62.3 \\
\hline 8.1 & 0.05883 & 0.00685 & 273.4 & 27.1 & 305.8 & 44.1 & 561.0 & 276.3 & 48.7 \\
\hline 10.1 & 0.10596 & 0.00089 & 1734.6 & 82.5 & 1733.0 & 47.3 & 1731.1 & 15.5 & 100.2 \\
\hline CT31 and CT & 32 -clasts of fels & ic volcanic-I & Itajaí conglomer & s (correctec & using measured & $204 \mathrm{~Pb})$ & & & \\
\hline $31-1.1$ & 0.06128 & 0.00321 & 810.4 & 18.6 & 768.6 & 33.2 & 649.1 & 116.8 & 124.8 \\
\hline $31-2.1$ & 0.06078 & 0.00822 & 579.8 & 19.0 & 590.4 & 66.5 & 631.6 & 321.8 & 91.8 \\
\hline $31-3.1$ & 0.05483 & 0.00591 & 603.4 & 17.8 & 563.5 & 51.3 & 405.4 & 261.2 & 148.8 \\
\hline $31-4.1$ & 0.05884 & 0.00221 & 606.9 & 17.3 & 597.3 & 23.2 & 561.2 & 84.2 & 108.1 \\
\hline $31-5.1$ & 0.05734 & 0.00238 & 646.0 & 15.4 & 615.4 & 23.9 & 504.5 & 94.2 & 128.1 \\
\hline $31-6.1$ & 0.0543 & 0.00236 & 592.7 & 22.1 & 551.2 & 26.7 & 383.6 & 100.6 & 154.5 \\
\hline $31-7.1$ & 0.05331 & 0.00344 & 597.1 & 14.7 & 546.7 & 31.1 & 341.9 & 153.1 & 174.7 \\
\hline $31-8.1$ & 0.05841 & 0.0022 & 630.9 & 21.1 & 612.6 & 25.4 & 545.3 & 84.5 & 115.7 \\
\hline $31-9.1$ & 0.05593 & 0.00235 & 606.6 & 15.2 & 574.5 & 23.2 & 449.7 & 96.0 & 134.9 \\
\hline $31-10.1$ & 0.06426 & 0.00153 & 641.4 & 48.2 & 666.0 & 42.4 & 750.2 & 51.3 & 85.5 \\
\hline $32-1.1$ & 0.05898 & 0.00205 & 591.3 & 17.6 & 586.2 & 22.3 & 566.2 & 77.4 & 104.4 \\
\hline $32-2.1$ & 0.06123 & 0.00158 & 645.2 & 21.0 & 645.7 & 21.9 & 647.2 & 56.5 & 99.7 \\
\hline
\end{tabular}


Table 3 continued

\begin{tabular}{|c|c|c|c|c|c|c|c|c|c|}
\hline Labels & $207 \mathrm{~Pb} / 206 \mathrm{~Pb}$ & $\pm 7 / 6$ & Age $206 / 238$ & \pm Age & Age $(207 / 235)$ & \pm age & Age $(207 / 206)$ & \pm age & Conc $(\%)$ \\
\hline $32-3.1$ & 0.06014 & 0.00101 & 580.7 & 21.7 & 586.5 & 20.0 & 608.7 & 36.8 & 95.4 \\
\hline $32-4.1$ & 0.05515 & 0.00612 & 599.9 & 22.1 & 563.3 & 54.1 & 418.2 & 269.1 & 143.5 \\
\hline $32-5.1$ & 0.06003 & 0.00111 & 648.9 & 16.4 & 639.1 & 16.3 & 604.5 & 40.5 & 107.3 \\
\hline $32-6.1$ & 0.06141 & 0.00135 & 619.3 & 11.0 & 626.7 & 14.4 & 653.7 & 47.9 & 94.7 \\
\hline $32-7.1$ & 0.05821 & 0.00168 & 607.9 & 27.6 & 593.3 & 26.7 & 537.8 & 64.5 & 113.0 \\
\hline $32-8.1$ & 0.05074 & 0.00287 & 580.9 & 16.9 & 514.5 & 27.6 & 229.1 & 136.3 & 253.5 \\
\hline $32-9.1$ & 0.06014 & 0.00351 & 585.8 & 14.0 & 590.5 & 30.1 & 608.5 & 131.5 & 96.3 \\
\hline $32-10.1$ & 0.05949 & 0.00247 & 610.3 & 10.8 & 605.0 & 21.9 & 584.9 & 92.8 & 104.3 \\
\hline $32-12.1$ & 0.05743 & 0.00382 & 582.4 & 31.7 & 567.5 & 41.1 & 508.0 & 153.2 & 114.7 \\
\hline $32-15.1$ & 0.05969 & 0.00132 & 621.9 & 14.7 & 615.6 & 16.4 & 592.4 & 48.6 & 105.0 \\
\hline $32-17.1$ & 0.0557 & 0.00561 & 596.9 & 29.7 & 565.4 & 52.9 & 440.5 & 241.2 & 135.5 \\
\hline $32-18.1$ & 0.05841 & 0.0013 & 603.8 & 16.7 & 591.6 & 17.5 & 545.1 & 49.3 & 110.8 \\
\hline $32-13.1$ & 0.13726 & 0.00102 & 2218.8 & 50.9 & 2205.4 & 26.4 & 2193.0 & 13.0 & 101.2 \\
\hline $32-14.1$ & 0.07592 & 0.00136 & 1186.3 & 51.5 & 1153.7 & 37.0 & 1092.9 & 36.2 & 108.5 \\
\hline $32-11.1$ & 0.06471 & 0.00101 & 778.2 & 20.4 & 774.8 & 18.3 & 765.0 & 33.1 & 101.7 \\
\hline $32-16.1$ & 0.06553 & 0.001 & 814.8 & 13.7 & 808.5 & 14.0 & 791.3 & 32.3 & 103.0 \\
\hline \multicolumn{10}{|c|}{ Felsic volcanic_-Apiúna Formation (corrected using measured 204Pb) } \\
\hline API-1.1 & 0.05958 & 0.00494 & 559.2 & 16.7 & 565.0 & 40.8 & 588.2 & 191.0 & 95.1 \\
\hline API-2.1 & 0.05804 & 0.00288 & 565.6 & 17.2 & 558.7 & 27.1 & 531.1 & 112.4 & 106.5 \\
\hline API-4.1 & 0.06 & 0.00189 & 560.7 & 12.6 & 569.2 & 18.3 & 603.5 & 69.7 & 92.9 \\
\hline API-5.1 & 0.05946 & 0.00307 & 559.1 & 14.1 & 564.1 & 26.6 & 584.1 & 116.1 & 95.7 \\
\hline API-6.1 & 0.05621 & 0.00286 & 545.1 & 14.8 & 529.1 & 25.6 & 460.6 & 117.1 & 118.3 \\
\hline API-3.1 & 0.04842 & 0.00743 & 550.4 & 17.8 & 474.1 & 63.0 & 119.8 & 326.5 & 459.5 \\
\hline \multicolumn{10}{|c|}{ Subida Granite (corrected using measured 204Pb) } \\
\hline A SUB-1.1 & 0.05413 & 0.00265 & 537.0 & 29.9 & 507.5 & 32.6 & 376.5 & 114.2 & 142.6 \\
\hline A SUB-2.1 & 0.05792 & 0.00302 & 539.6 & 30.4 & 537.2 & 35.3 & 526.9 & 118.4 & 102.4 \\
\hline A SUB-3.1 & 0.05594 & 0.00157 & 518.1 & 40.5 & 505.7 & 36.1 & 449.9 & 63.5 & 115.2 \\
\hline A SUB- 4.1 & 0.05606 & 0.00278 & 537.2 & 28.9 & 521.7 & 32.8 & 454.6 & 113.9 & 118.2 \\
\hline A SUB-5.1 & 0.05566 & 0.00382 & 522.7 & 33.2 & 507.4 & 41.1 & 439.0 & 160.5 & 119.1 \\
\hline A SUB-6.1 & 0.05566 & 0.00227 & 537.7 & 23.8 & 519.3 & 26.9 & 439.0 & 93.6 & 122.5 \\
\hline C SUB-7.1 & 0.05866 & 0.00223 & 525.1 & 25.8 & 530.6 & 28.2 & 554.4 & 85.0 & 94.7 \\
\hline C SUB-8.1 & 0.05504 & 0.00205 & 509.0 & 26.7 & 492.0 & 27.6 & 413.9 & 85.7 & 123.0 \\
\hline C SUB-9.1 & 0.0556 & 0.00205 & 509.6 & 27.7 & 496.5 & 28.3 & 436.4 & 84.3 & 116.8 \\
\hline C SUB-10.1 & 0.05587 & 0.00172 & 528.4 & 22.0 & 513.4 & 22.9 & 447.2 & 70.0 & 118.2 \\
\hline C SUB-11.1 & 0.05624 & 0.00102 & 521.7 & 26.2 & 510.7 & 23.3 & 461.9 & 40.5 & 113.0 \\
\hline C SUB-12.1 & 0.05807 & 0.00053 & 534.1 & 25.1 & 533.8 & 21.3 & 532.4 & 20.1 & 100.3 \\
\hline NC SUB-2.1 & 0.05635 & 0.00398 & 517.8 & 16.9 & 508.4 & 33.4 & 466.4 & 164.6 & 111.0 \\
\hline NC SUB-3.1 & 0.05608 & 0.00474 & 522.7 & 16.2 & 510.4 & 38.5 & 455.4 & 199.3 & 114.8 \\
\hline NC SUB-7.1 & 0.0528 & 0.00607 & 516.3 & 15.4 & 481.7 & 48.2 & 320.3 & 284.7 & 161.2 \\
\hline NC SUB-1.1 & 0.05521 & 0.00318 & 598.6 & 16.1 & 562.8 & 29.5 & 420.7 & 133.9 & 142.3 \\
\hline NC SUB-4.1 & 0.04581 & 0.02987 & 515.4 & 22.3 & 429.0 & 261.7 & 0.0 & 0.0 & 0.0 \\
\hline NC SUB-5.1 & 0.02593 & 0.02533 & 481.7 & 25.1 & 248.6 & 244.4 & 0.0 & 0.0 & 0.0 \\
\hline NC SUB-6.1 & 0.03829 & 0.01468 & 524.6 & 18.4 & 375.6 & 130.4 & 0.0 & 0.0 & 0.0 \\
\hline NC SUB-8.1 & 0.05128 & 0.00714 & 480.3 & 16.0 & 442.9 & 54.4 & 253.4 & 292.0 & 189.5 \\
\hline
\end{tabular}

Laboratory: A = RSES (Australia); $\mathrm{C}=\mathrm{BSC}$ (China); NC = new data from BSC (China)

Labels: $\mathrm{x}, \mathrm{y}$; grain number followed by analysis number

Grain habit: $p$ prism, anh anhedral, $f r$ fragment

Site: $e$ end or edge, $m$ middle, int interior, og overgrowth, $c$ core

CL image microstructure, osc oscillatory finescale zoning, rex recrystallised, $h$ homogeneous ( $d$ dark, $b$ bright)

Data corrected with model $\mathrm{Pb}$ of Cumming and Richards (1975) for likely age of rock; all errors are $1 \mathrm{~s}$ 

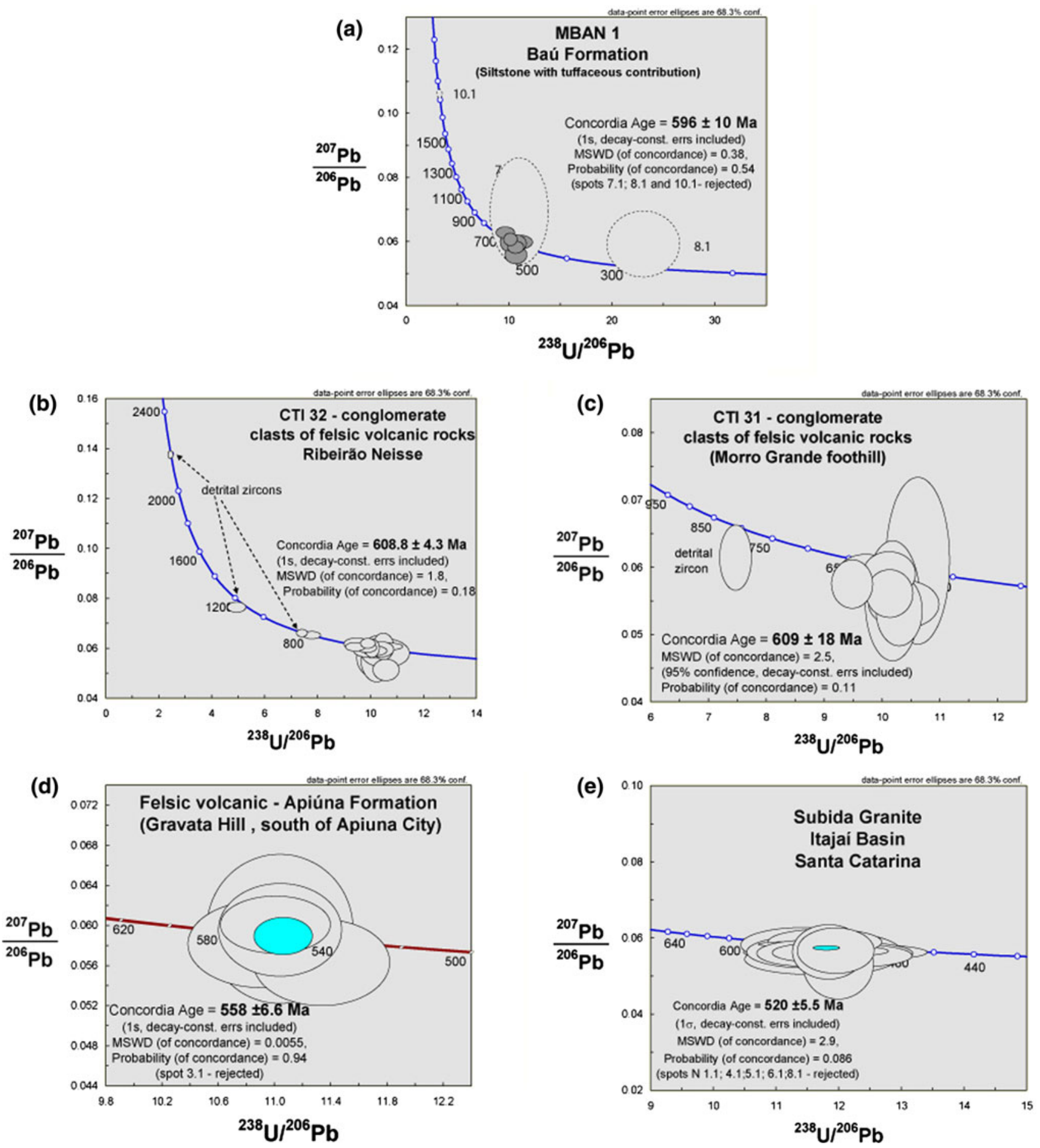

Fig. 17 a U-Pb diagram for the tuffaceous levels (sample MBAN 1) intercalated within Baú Formation arkosic sandstones (close to the Ribeirão do Russo, south of Blumenau). The age obtained from volcanogenic zircons constrains the oldest age limit possible for the sedimentation of the Itajaí Group lower unit; $\mathbf{b}, \mathbf{c} \mathrm{U}-\mathrm{Pb}$ plots for zircons extracted from felsic volcanic rocks that occurs as subdecimeter-sized $(1-3 \mathrm{~cm})$ in the Itajaí Group conglometares (b sample CT31 - foot of Morro Grande, left bank of the Itajaí Açu river, in the

proximity of Apiúna; c CT32 -thick conglomerate level in the upper Neisse river); d U-Pb diagram for the Morro do Gravatá felsic volcanic rock. The age obtained constrains the youngest age limit possible for the Itajaí Group sedimentation; e U-Pb diagram for the Subida leucosyenogranite. The Cambrian age obtained for this granitoid intrusive in the Itajaí Group attests for its anorogenic character and rules out any relationship with the much older Serra do Mar Suite 
Fig. 18 Dated Rocks

a Volcanic tuffs associated with sandy levels intercalated with

Baú Formation conglomerates, south of Blumenau, close to Ribeirão do Russo; b Polymictic conglomerate with abundant felsic volcanic rock clasts; c Acid volcanic rock of Apiúna Formation, Morro do Gravata, south of Apiúna; d Pink facies of the Subida syenogranite
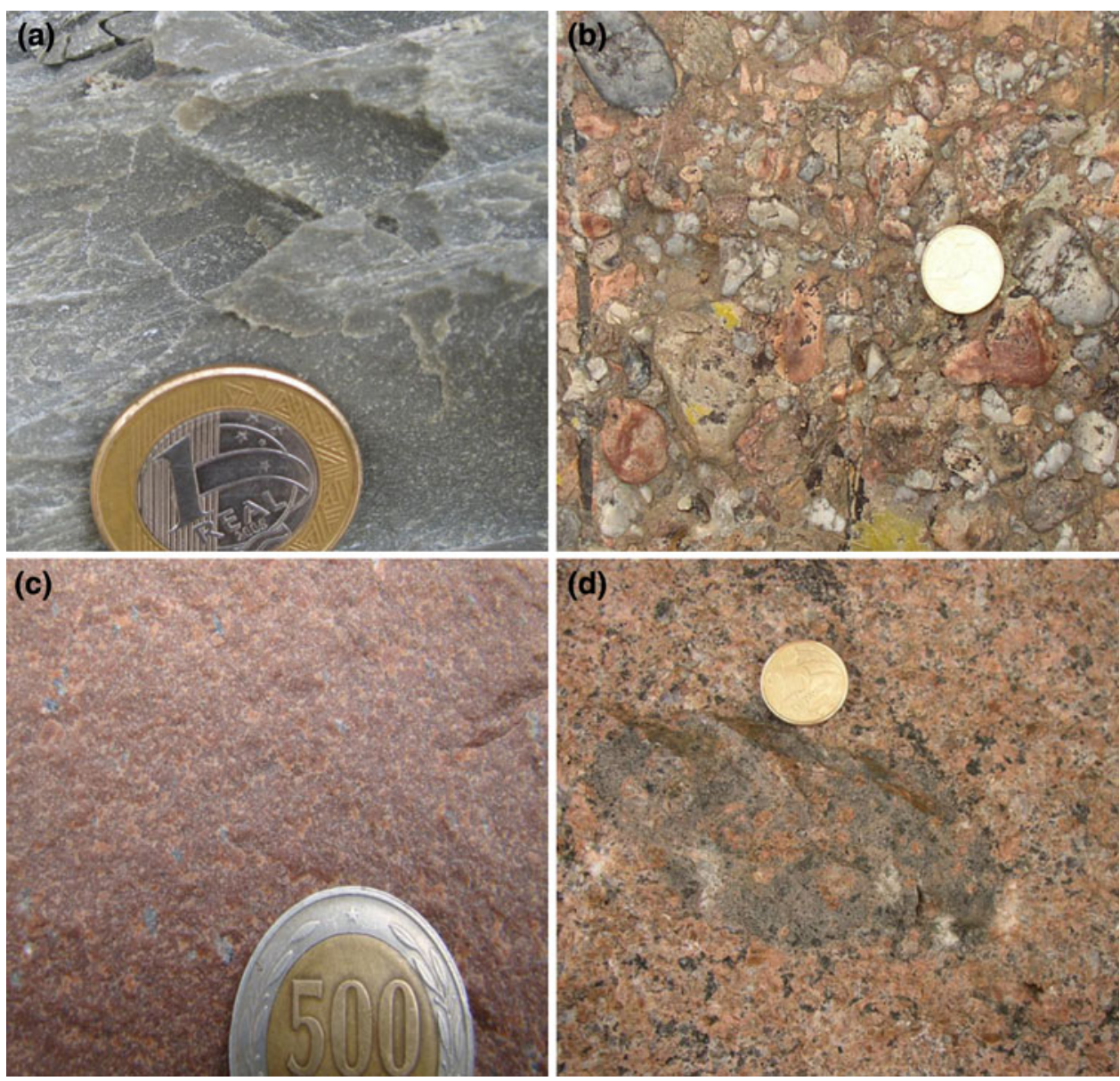

et al. 2010) and zircons from igneous rocks (this manuscript), which means that the former results complement the latter.

The interpretations based on $(\mathrm{Sr}, \mathrm{Nd}$, and $\mathrm{Pb})$ isotopes presented in both papers are very harmonious, indicating that the Dom Feliciano Belt was the main source of material for the Itajaí Basin intermediate and upper sedimentary units. The Santa Catarina Granulitic Complex is indicated in both papers as the main candidate as source for the sandstones and conglomerates that composes the basal portion of the Itajaí Basin. Therefore, both groups of researchers agree with the classification of the Itajaí Basin as a peripheral foreland basin located between the Dom Feliciano Belt to the south and the stable and old terranes to the north.

However, some divergences appear regarding the results achieved, when specific points are compared. The ages obtained for tuffs and acid volcanic rocks, which define the limit values for the beginning and the end of the deposition of the Itajaí Group sedimentary units, are not concordant. The interval between 596 and $560 \mathrm{Ma}$ presented in this work is older than the 563-549 Ma interval proposed by Gaudagnin et al. (2010).

A lower limit of $596 \mathrm{Ma}$ is very close to the age of volcanism observed for the Campo Alegre Basin, which would place the deposition of both basins closer in time. This age is also closer to the well-controlled age of the basal portion of the Camaquã Basin and also is in agreement with the recently determined deposition interval for the Arroyo del Soldado Formation in Uruguay (Basei, in preparation). The older age for the beginning of the Itajaí Group deposition is compatible with the age of detrital zircons presented by Guadagnin et al. (2010), the younger populations from lower units of the Itajaí Basin indicating values around $590 \mathrm{M}$. Only for the upper unit of the base of siltites, the younger population of detrital zircons yields ages around $563 \mathrm{Ma}$, both within the interval proposed in this paper.

On the other hand, the upper limit for the deposition of the sediments is given by the age of the felsic rocks that affect the Basin sediments. The values for this magmatism were obtained in both papers by dating the Gravatá dome felsic rocks (south of Apiúna). The results were 558 and $549 \mathrm{Ma}$, the older presented in this paper. One of the possible causes for such difference can be attributed to the methods used-LA ICPMS by Guadagnin et al. (2010) and SHRIMP (our work).

Other divergent points reside in the implications that result from the different stratigraphic columns presented in 
both works. In our paper, sandstones, conglomerates, and acid tuffs that occur on the southern border of the Itajaí Basin are interpreted as a tectonic recurrence of the Bau Formation (lower unit), whereas in Guadagnin et al. (2010) these rocks integrate the upper unit, which would indicate the return of continental conditions that predominated in the beginning of the Itajaí Basin evolution. Our stratigraphy reflects the reading of the geological map presented in this paper, where the modifications introduced by the epidermal tectonics, which deforms the basin, characterizes it as a typical example of a thrust and fold belt, and explains the occurrence of the same rocks on both borders. The major deformation of the southern border units, the similarities observed in the sedimentary associations of both borders, a compatible isotopic signature $(\mathrm{Nd}$ and $\mathrm{Pb})$ and comparable provenance ages, led us to consider that a more correct interpretation is that the rocks from both borders compose a single lithostratigraphic unit.

Another point in favor of a proposal that involves the repetition of the lower unit in the southern border is the pattern yielded by detrital zircons presented by Guadagnin et al. (2010), which shows that the provenance of the zircons from sandstones and conglomerates attributed by these authors to the upper units is similar to the pattern presented by the lower units that occur on the northern border (Bau Formation) and quite different from the ages observed at the base of the siltite unit, which for us represents the true top of the Itajaí Basin, that yields detrital zircon ages restricted to Neoproterozoic values.

\section{Conclusions}

The integrated approach, involving information coming from cartography, lithostratigraphy, structural geology, lithogeochemistry, isotopic geochemistry, and geochronology, helped reinforce a new and more detailed interpretation for the Itajaí Basin tectonic evolution.

The proposed lithostratigraphic column assigns the Itajaí Group rocks into two major sequences: a basal continental and an upper marine sequence. The lower sequence (the Baú Formation) is represented by sandstones and conglomerates deposited in alluvial and retrograding deltaic fan systems, with facies varying from gravelly and sandy deltaic plain, grading to proximal and distal deltaic front, to prodelta. This sequence grades laterally and toward the top to the upper sequence, constituted by the Ribeirão Carvalho Formation rhythmites, which represent the proximal channelized and non-channelized turbiditic facies, the Ribeirão Neisse Formation arkosic sandstones, and laminated siltites of the Ribeirão do Bode Formation distal turbiditic facies.

Based on the similarities between the sandstones and conglomerates that occur in both borders of the Itajaí
Basin, it is emphasized that these rock types belong to the Baú Formation. Besides the similar geochemical-isotopic characteristics, the continuity of these rocks can be checked in the geologic map, which shows the Pedra de Amolar region as the junction between the units of both borders. The proposal that the sandstones with continental characteristics that occur in the southern border represent a third unit is thus ruled out. They in fact represent tectonic repetitions of the basal unit by inverse faulting.

The structural studies indicate that the intensity of phase D1 was highest in the SE portion of the Itajai Basin, close to the orogenic belt, with NE-SW axial orientation characterized by folds with vertical axial planes close to the northern border, grading to megafolds of inverse flanks, inverse faults and thrusting in the southern portion, with clear tectonic vergence to $\mathrm{NW}$, toward the foreland. Thrusting with a NW direction of transport and preferentially affecting the southern border of the Basin is associated with this phase. Phase D2 is restricted to discontinuous folds of large wavelength and approximately $\mathrm{N}-\mathrm{S}$ axial orientation and slight southwards plunge. The interference of phase D2 on phase D1 is observed at various scales, in the outcrops and in the regional map. These phases are directly related to the deformational phases that followed the metamorphic climax in the Brusque Group.

The study of the susceptibility anisotropy and remanent magnetization in two sites of the Gravata rhyolitic dome has shown that these igneous rocks were affected only by the Itajaí Basin second deformational phase, which places the first phase between 600 and $560 \mathrm{Ma}$ and the second phase syn- to post-560 Ma. Additionally, this chronology of events indicates, in agreement with the information obtained by magnetostratigraphy, a short period between deposition and deformation phase D1, implying possible syn-tectonic sedimentation (Drukas 2009).

The lithogeochemical (major, trace and rare earth elements) and isotopic $(\mathrm{Sr}, \mathrm{Nd}$ and $\mathrm{Pb}$ ) analyses of the sedimentary rocks gives support to the proposed lithostratigraphic column. A very homogeneous behavior is observed in the units that compose the upper sequence, which is at the same time significantly different from that of the lower sequence. Among the various tectonic settings possible, it is proposed that the precursors of the Itajai Group sediments were generated in settings geochemically associated with continental collision, passive margins and magmatic arcs. The probable candidates to source areas of the upper sequence sediments, with marked contribution from the upper crust, are the Brusque Group and the Florianópolis Batholith. The proposed candidates for the continental and lower units, whose geochemical signature shows considerable contribution from reworked old crust, are the terranes of the Luis Alves, São Miguel, and Camboriú Complexes. 
The Itajaí Basin is thus interpreted as a peripheral foreland basin directly related to the evolution of the Dom Feliciano Belt. The late-collisional shortening of the fold belt, represented by the Brusque Group, led to the formation of the Itajaí Basin by flexural subsidence. The deposition of the basal continental sequence started with the erosion of its basement, notably the Santa Catarina Granulitic Complex, with some contribution from the Dom Feliciano Belt. With the increasing proximity of the adjacent Brusque Group orogenic belt and the Florianópolis Batholith (magmatic arc), these became the main sources for the sediments of the upper, turbiditic marine sequences. The Itajaí Basin and the Brusque Group would then be situated in the lower plate of this passive margin context (Luís Alves Microplate southern border), whereas the Florianópolis Batholith, representing the roots of a Neoproterozoic magmatic arc, south of the Major Gercino Suture Zone, would be situated in the upper plate in the active margin setting. The generation of the Itajaí Basin occurred in a late-collisional setting that followed the termination of the subduction of oceanic crust southeastwards, around $600 \mathrm{Ma}$.

The lack of records indicating a rift-type opening leading to the development of an oceanic crust implies that the Itajaí Basin upper marine units were deposited in an environment similar to a restricted and internal sea. The geologic history of the Itajaí Basin must have started around $600 \mathrm{Ma}$, with the deposition of the lower units on the gneisses of the Luís Alves Microplate southern border. Around $560 \mathrm{Ma}$, the sedimentation ceased, as attested by the Apiúna Formation felsic magmatism, expressed as dikes and domes crosscutting the whole sedimentary succession. The emplacement of the felsic volcanism after the first deformation phase (Drukas 2009) implies a maximum time interval of $40 \mathrm{Ma}$ for the deposition and the first deformation phase. In the Cambrian, close to $520 \mathrm{Ma}$, after the stabilization of the Itajaí Basin, the intrusion of the anorogenic Subida leucosyenogranite took place.

Based on the available radiometric data, it is demonstrated that the deposition of the Itajai Basin was exclusively restricted to the Neoproterozoic. Respecting the differences inherent to the details acquired during their evolutions, the Itajaí Basin can be temporally and tectonically correlated with the Camaquã Basin in Rio Grande do Sul (Pain et al. 1990, Fragoso Cesar 1991) and the Arroyo del Soldado/Piriápolis Basin in Uruguay (Gaucher and Sprechmann 1998, Gaucher et al. 1996, 2009). It also presents several tectonic-sedimentary characteristics in common with the Nama Basin, its equivalent in Africa (Gresse et al. 1996, Frimmel and Miller 2009, Germs et al. 2009; Guadanin et al. 2010).

Acknowledgments The authors are grateful to many colleagues of the Institute of Geosciences-USP for the fruitful discussions. Most of field and laboratory work were supported by grants from the São Paulo State Foundation of Research Support (FAPESP—2005/58688-1).

\section{References}

Appi CJ (1991) Análise estratigráfica da seção metassedimentar do Grupo Itajaí no estadode Santa Catarina. Dissertation, Federal University of Rio de Janeiro

Appi CJ, Cruz CES (1990) Estratigrafia de sequiências na Bacia do Itajaí. In: Cong. Bras. Geol., 36, Natal, Anais, vol 1. Natal, SBG. pp 93-106

Basei MAS (1985) O Cinturão Dom Feliciano em Santa Catarina. Unpublished Ph.D thesis, University of São Paulo.191 pp

Basei MAS (2000) Geologia e modelagem geotectônica dos terrenos Pré-Cambrianos das regiões Sul- Oriental brasileira e uruguaiana: possíveis correlações com províncias similares do sudoeste africano. Livre Docência Thesis, University of São Paulo. p 18

Basei MAS, Siga O Jr, Machiavelli A, Mancini F (1992) Evolução tectônica dos terrenos entre os Cinturões Ribeira e Dom Feliciano (PR - SC). Rev Bras Geoc 22(2):216-221

Basei MAS, Citroni SB, Siga O Jr (1998a) Stratigraphy and age of fini-Proterozoic basins of Paraná and Santa Catarina States, Southern Brazil. Bol IG-USP, Sér Cient 29:195-216

Basei MAS, McReath I, Siga O Jr (1998b) The Santa Catarina granulite complex of Southern Brazil, a review. Gond Res 1:383-391

Basei MAS, Siga O Jr, Cordani UG, Sato K, Lima PS (1999) The magmatism of the Itajaí Basin, SC, Southern Brazil, and its importance to define the Proterozoic-Phanerozoic limit. II South American symposium on isotope Geology, Cordoba, Argentina, Actas, pp 287-290

Basei MAS, Frimmel HE, Nutman AP, Preciozzi F, Jacob J (2005) The connection between the Neoproterozoic Dom Feliciano (Brazil/Uruguay) and Gariep (Namibia/South Africa) orogenic belts. Prec Res 139:139-221

Basei MAS, Frimmel HE, Nutman AP, Preciozzi F (2008a) West Gondwana amalgamation based on detrital zircon ages from Neoproterozoic Ribeira and Dom Feliciano belts of South America and comparison with coeval sequences from SW Africa. Geol Soc Spec Public 294:239-256

Basei MAS, Drukas CO, Santos PR, Osako L, Arcaro NP (2008b) Estratigrafia, idade e proveniência dos sedimentos da Bacia do Itajaí, SC, Brasil. In: $44^{\circ} \mathrm{CBG}$, Anais, SBG,Curitiba

Basei MAS, Grasso C, Vlach SRF, Nutman AP, Siga O Jr, Osako LS (2008c) A-type rift related granite and the Lower Cryogenian age for the beginning of the Brusque Belt basin. In: South American Symposium on Isotope Geology, 6, San Carlos de Bariloche, Argentina. Proceedings, CD-ROM

Basei MAS, Nutman A, Siga O Jr, Passarelli CR, Drukas CO (2009) The evolution and tectonic setting of the Luis Alves Microplate of Southeastern Brazil: an exotic terrane during the assembly of Western Gondwana. In: Gaucher C, Sial AN, HalversonGP, Frimmel HE (eds) Neoproterozoic-Cambrian tectonics, global change and evolution: a focus on southwestern Gondwana, vol 16. Develop Prec Geol, pp 273-291

Carvalho PF,Pinto EA (1938) Reconhecimento Geológico no Estado de Santa Catarina. DGM/DNPM, Rio de Janeiro. Boletim (92):30

Citroni SB (1993) Ambientes deposicionais e significado geotectônico da sedimentação do Grupo Itajaí-SC. Master Thesis, University of São Paulo

Compston W, Williams IS, Meyer C (1984) U-Pb geochronology of zircons from lunar breccia 73217 using a sensitive high massresolution ion microprobe. J Geophys Res Supp 89:525-534 
Cumming GL, Richards JR (1975) Ore lead isotope ratios in a continuously changing Earth. Earth Plan Sci Lett 28:155-171

DePaolo DJ (1988) Neodymium isotope geochemistry. Springer, Berlin, $187 \mathrm{p}$

Dickinson WR (1974) Plate tectonics and sedimentation. In: Dickinson WR (ed) Tectonic and sedimentation, special publication society of economic paleontologists and mineralogists, 22. Tulsa, Oklahoma, pp 1-272

Drukas CO (2009) Estratigrafia, estudos magnéticos e proveniência dos sedimentos da Bacia do Itajaí, SC. TF-2009/05, Geosciences Institute, USP, São Paulo, 68p

Faure EG (2005) Principles of isotope geology. Willey. New York, $589 \mathrm{pp}$

Floyd PA, Leveridge BE (1987) Tectonic environment of the Devonian Gramscatho basin, south Cornwall: frame work mode and geochemical evidence from turbiditic sandstones. J Geol Soc 144:531-542

Fonseca MM (2004) Sistemas Deposicionais e Estratigrafica de Sequiências da Bacia do Itajaí (SC) e Detalhamento do Complexo Turbidítico Apiúna. PhD thesis, UNISINOS

Fragoso Cesar ARS (1991) Tectonica de Placas no Ciclo Brasiliano: As orogenias dos cinturões Dom Feliciano e Ribeira no Rio Grande do Sul. PhD thesis, University of São Paulo

Freitas RO (1945) O Conglomerado do Baú (Serie Itajaí - SC). Bol Inst Geo Fac Filos Letras USP 2:37-115

Frimmel HE, Miller RM (2009) Continental rifting. Neoproterozoic to early palaeozoic evolution of Southwestern Africa In: Gaucher C, Sial AN, Halverson GP, Frimmel HE (eds) NeoproterozoicCambrian tectonics, global change and evolution: a focus on Southwestern Gondwana. Elsevier, Amsterdam, pp 153-159

Gaucher C, Sprechmann P (1998) Grupo Arroyo del Soldado: Paleontologia, Edad y Correlaciones (Vendiano-Cambrico Inferior, Uruguay). Actas del II Gongreso Uruguayo de Geologia, Punta del Este, Uruguay, pp 183-187

Gaucher C, Sprechmann P, Schipilov A (1996) Upper and middle proterozoic fossiliferous sedimentary sequences of the Nico Perez Terrane of Uruguay: lithostratigraphic units, paleontology, depositional environments and correlations. N Jb Geol Palänont Abh 199(3):339-367

Gaucher C, Frimmel HE, Germs GJB (2009) Tectonic events and palaeogeographic evolution of southwestern Gondwana in the Neoproterozoic and Cambrian In: Gaucher C, Sial AN, Halverson GP, Frimmel HE (eds) Neoproterozoic tectonics, global change and evolution: a focus on Southwestern Gondwana. Elsevier, Amsterdam, pp 295-316

Germs GJB, Miller RM, Frimmel HE, Gaucher C (2009) Syn- to lateorogenic sedimentary basins of southwestern Africa. Neoproterozoic to Early Palaeozoic evolution of Southwestern Gondwana In: Gaucher C, Sial AN, Halverson GP, Frimmel HE (eds) Neoproterozoic tectonics, global change and evolution: a focus on Southwestern Gondwana. Elsevier, Amsterdam, pp 183-203

Gresse PG, Chemale F, Silva LC, Walraven F, Hartmann LA (1996) Late to post-orogen basins of Pan-African-Brazilian collision orogen in southwest Africa and southern Brazil. Basin Res $8: 157-171$

Guadagnin F (2007) Idade e proveniência das rochas sedimentares da Bacia do Itajaí. Porto Alegre, RS, Trabalho de Conclusão de Curso, IGEO/UFRGS, $119 \mathrm{pp}$

Guadagnin F, Chemale Jr. F, Dussin IA, Jelinek AR, Santos MN, Borba ML, Justino D, Bertotti AL, Alessandretti L (2010) Depositional age and provenance of the Itajaí Basin, Santa Catarina State, Brazil: implications for SW Gondwana correlation. Precambrian Res 180(3-4):156-182

Harara OMM (2001) Mapeamento e investigação petrológica e geocronológica dos litotipos da região do Alto Rio Negro (PR-SC): Um exemplo de sucessivas e distintas atividades magmáticas durante o Neoproterozóico. PhD Thesis, University of São Paulo

Harara OMM, Basei MAS, Siga O Jr (2002) From subduction to late and post-collision settings: a record from Neoproterozoic sucessive magmatic in the upper Rio Negro region. In: XXXXI Congresso Brasileiro de Geologia, João Pessoa, PB, vol 1, p 310

Hartmann LA, Silva LC, Orlandi V (1979) O Complexo Granulítico de Santa Catarina. Acta Geológica Leopoldensia 6:94-112

Herron MM (1988) Geochemical Classification of Terrigenous Sands and Shales from core or log data. J Sediment Petrol 58(5): $820-829$

Kaul PFT (1976) Projeto Brusque Serra do Tabuleiro. Convênio DNPM/CPRM. Porto Alegre, Brasil. $165 \mathrm{p}$

Kaul PFT (1980) O Cráton Luis Alves. Camboriú, SC. In: Congresso Brasileiro de Geologia 31, vol 5, pp 2677-2683

Kaul PFT (1984) Significado dos granitos anorogênicos da Suíte Intrusiva Serra do Mar na evolução da crosta no sul-sudeste do Brasil no âmbito das folhas SG.22-Curitiba e SG.23-Iguape. In: Congresso Brasileiro de Geologia 33, vol 6, pp 2815-2825

Krebs ASJ, Caldasso ALS, Lopes RC (1988) Interpretação preliminar da seqüência deposicional da Bacia do Itajaí na área da folha Botuverá. In: Congresso Brasileiro de Geologia 35, vol 2, pp 592-605

Krebs ASJ, Silva MA, Dias AA, Camozzato E, Lopes RC (1990) O Grupo Itajaí na folha Botuverá (SC). Modelo geométricocinemático e relações com o Cinturão granulítico e Cinturão Metavulcano-Sedimentar Brusque. In: Congresso Brasileiro de Geologia 36, vol 6, pp 2966-2975

Ludwig KR (2001) Using Isoplot/Ex. A geochronological toolkit for Microsoft Excel. Berkeley Geochronology Center, Special Publications 1. Berkeley, USA

Maack R (1947) Breves notícias sobre a geologia dos estados do Paraná e Santa Catarina. Arq Biol Tecnol 2:63-154

Macedo MHF, Basei MAS, Bonhomme M, Kawashita K (1984) Dados geocronológicos referentes às rochas metassedimentares do Grupo Itajaí, Santa Catarina. Ver Bras Geoc 14(1):30-34

Machiavelli A, Basei MAS, Siga O Jr (1993) Suíte Granítica Rio Piên: um arco magmático do Proterozóico superior na Microplaca Curitiba. Geochem Brasiliensis 7:113-129

McLennan SM, Taylor SR (1985) The continental crust: its composition and evolution. Blackwell, Oxford, $311 \mathrm{p}$

McLennan SM, Taylor SR, McCulloch MT, Maynard JB (1990) Geochemical and $\mathrm{Nd}-\mathrm{Sr}$ isotopic composition of deep-sea turbidites: crustal evolution and plate tectonic associations. Geochim Cosmochim Acta 54:2015-2050

McLennan SM, Hemming SR, Taylor SR, Erickson K (1995) Early proterozoic crustal: geochemical and Nd-PB isotopic evidence from metasedimentary rocks, southwestern North America. Geochim Cosmochim Acta 59(6):1153-1177

Pain PSG, Faccini UF, Netto RG, Nowatski CH (1990) Estratigrafia das Bacias do Camaquã e Santa Barbara, Eo-Paleozoico do Rio Grande do Sul (Brasil). In: IGCP 270 workshop-Eventos do Paleozoico Inferior da America latina e suas relações com a gênese de Gondwana. São Paulo. IG-USP

Pain PSG, Leipnitz II, Rosa ANZ, Rosa AAS (1997) Preliminary report on the occurrence of Chancelloria sp. In the Itajaí Basin, southern Brazil. Rev Bras Geoc 27(3):303-308

Pettijohn FJ, Potter PE, Siever R (1972) Sand and sandstone. Springer, Heidelberg $618 \mathrm{p}$

Rollinson H (1993) Using geochemical data: evaluation, presentation, interpretation. Longman

Rostirolla SP (1991) Tectônica e Sedimentação da Bacia de ItajaíSC. Umpublished Master Thesis - UFOP, Ouro Preto MG, $132 \mathrm{p}$

Rostirolla SP, Alkimin FF, Soares PC (1992) O Grupo Itajaí, Estado de Santa Catarina, Brasil, exemplo de sedimentação em uma bacia flexural de antepaís. Bol Geoc Petrobrás 6(3/4):109-122 
Rostirolla SP, Ahrendt A, Soares PC, Carmingnani L (1999) Basin analysis and mineral endowment of the Proterozoic Itajaí Basin, south-east Brazil. Basin Res 11:127-142

Salamuni R, Bigarella JJ, Takeda FK (1961) Considerações sobre a estratigrafia e tectônica da Série Itajaí. Curitiba PR Bol Par Geogr 415:188-201

Santos JPP, Bettini C, Moraes MAS (2008) Representação espacial de lobos e canais turbidíticos em afloramentos da região de Apiúna, Bacia do Itajaí, Santa Catarina. Bol Geoc Petrobrás 16:69-85

Sato K, Siga O Jr, Nutman AP, Basei MAS, McReath I, Kaulfuss G (2003) The Atuba complex, Southern South American platform: archean components and paleoproterozoic to neoproterozoic tectonothermal events. Gond Res 6(2):51-263

Schulz A Jr, Albuquerque LFF, Rodrigues CS (1970) Geologia da Quadrícula de Florianópolis, SC. DNPM. Porto Alegre, Brasil, 75 p

Siga O Jr, Basei MAS, Reis Neto JM, Machiavelli A, Harara OM (1995) O Complexo Atuba: um cinturão Paleoproterozóico intensamente retrabalhado no Neoproterozóico. Boletim IG-USP Série Científica 26:69-98

Siga O Jr, Basei MAS, Passarelli CR, Sato K, Cury LF, Mcreath I (2009) Magmatic records of lower neoproterozoic and upper neoproterozoic in Itaiacoca Belt (Paraná-Brazil): zircon ages and lithostratigraphy studies. Gondwana Res 197-208

Silva LC, Dias AA (1981) Projeto Timbó-Barra Velha, Brasil. Convênio DNPM/CPRM. Porto Alegre. $282 \mathrm{p}$

Sircombe KN (2000) Quantitative comparison of large data sets of geochronological data using multivariate analysis: a provenance study example from Australia. Geochimica Cosmochimica Acta 64:1593-1616

Stern RA (1998) High resolution SIMS determination of radiogenic trace-isotope ratios in minerals. In: Cabri LJ, Vaughan DJ (eds) Modern approches to ore and environmental mineralogy. Short Course Series, Mineral Assoc, Canada, pp 241-268

Vlach SRF, Gualda GAR (2007) Allanite and chevkinite in A-type granites and syenites of the Graciosa Province, southern Brazil. Lithos 97:98-121

Williams IS (1998) U-Th-Pb geochronology by ion microprobe. In: McKibben MA, Shanks III WC, Ridley WI (eds) Applications of microanalytical techniques to understanding mineralising processes. Society of Economic Geologists, Reviews in Economic Geology 7:1-35 